Regulatory Integration of International Capital Markets 
The Working Paper series of the Oesterreichische Nationalbank is designed to disseminate and to provide a platform for discussion of either work of the staff of the OeNB economists or outside contributors on topics which are of special interest to the OeNB. To ensure the high quality of their content, the contributions are subjected to an international refereeing process. The opinions are strictly those of the authors and do in no way commit the OeNB.

The Working Papers are also available on our website (http://www.oenb.at) and they are indexed in RePEc (http://repec.org/).

Publisher and editor

Editorial Board

of the Working Papers

\section{Coordinating editor}

Design

DVR 0031577

ISSN 2310-5321 (Print)

ISSN 2310-533X (Online)

(C) Oesterreichische Nationalbank, 2017. All rights reserved.

Oesterreichische Nationalbank

Otto-Wagner-Platz 3, 1090 Vienna, Austria

PO Box 61, 1011 Vienna, Austria

www.oenb.at

oenb.info@oenb.at

Phone (+43-1) 40420-6666

Fax (+43-1) 40420-046698

Doris Ritzberger-Grünwald, Ernest Gnan, Martin Summer

Martin Summer

Communications and Publications Division 


\section{Editorial}

On the occasion of the 65th birthday of Governor Klaus Liebscher and in recognition of his commitment to Austria's participation in European monetary union and to the cause of European integration, the Oesterreichische Nationalbank (OeNB) established a "Klaus Liebscher Award". It has been offered annually since 2005 for up to two excellent scientific papers on European monetary union and European integration issues. The authors must be less than 35 years old and be citizens from EU member or EU candidate countries. Each "Klaus Liebscher Award" is worth EUR 10,000. The two winning papers of the thirteenth Award 2017 were written by Filippo De Marco and by Jean-Marie Meier. The latter paper is presented in this Working Paper while Filippo De Marco’s contribution is contained in Working Paper 213.

June 1, 2017 


\title{
Regulatory Integration of International Capital Markets*
}

\author{
Jean-Marie A. Meier \\ June 1, 2017 \\ Latest version: click here
}

\begin{abstract}
I examine the financial and real effects of regulatory integration of international capital markets using a unique policy plan by the European Union, which creates a common European market for financial services and capital, through, e.g., passporting rights. For identification, I exploit the bilateral and staggered nature of laws that are passed at the European level but are implemented by national governments. Over its implementation, regulatory integration leads to large increases in external financing, investment and employment for publicly listed firms. These results highlight the importance of regulatory integration of international capital markets for firms' financing decisions and real outcomes.
\end{abstract}

Keywords: International law, regulation, integration, passporting rights, capital markets, external finance, real effects.

JEL classification: F36, G15, G18, G28, G30, K22, K33.

\footnotetext{
*I am deeply grateful to my advisor Henri Servaes for his invaluable and continuous support. I thank Taylor Begley, Bo Bian, Hans Christensen, João Cocco, James Dow, Alex Edmans, Anna-Sophia Elm, Julian Franks, Francisco Gomes, Giovanni Guazzarotti, Christopher Hennessy, Ralph Koijen, Stefan Lewellen, Frédéric Malherbe, Pedro Matos, David Müller, Florian Nagler, Clemens Otto, Elias Papaioannou, Arkodipta Sarkar, David Schoenherr, Ishita Sen, Amit Seru, Rui Silva, Jan Starmans, Vikrant Vig, Luofu Ye, and seminar participants at BI Norwegian Business School, City University of Hong Kong, European Central Bank, Goethe University Frankfurt, London Business School, Ohio State University, University of Hong Kong, University of Texas at Dallas, University of Virginia Darden, and conference participants at the 2017 RFS Conference on Banks, Systemic Risk, Measurement and Mitigation. Thanks also to the Deloitte Institute of Innovation and Entrepreneurship at London Business School for providing financial support.

${ }^{\dagger}$ London Business School, Regents Park, London NW1 4SA, United Kingdom. Email: jmeier@london.edu. Homepage: http://www.jean-mariemeier.com.
} 


\section{Introduction}

In recent decades, financial regulation has changed significantly, for instance with the Dodd-Frank Act in the United States and the Basel Accords internationally. But what should be the geographical scope of such laws? For example, should securities laws be designed at a regional level as in Canada or at the national level as in the United States? Or should such laws be designed internationally as in the European Union? On the one hand, regulatory integration can lead to more competition and as a result to increases in real outcomes (Jayaratne and Strahan (1996), Black and Strahan (2002)), and it can avoid regulatory arbitrage (Bebchuk (1992), Houston, Lin, and Ma (2012)).

On the other hand, regulatory integration does not take the heterogeneity of the involved areas into account (Stiglitz (2002)) and prevents the benign aspects of regulatory competition across jurisdictions (Revesz (1992), Coffee Jr. (2002), Karolyi and Taboada (2015)).

I contribute to this debate by establishing that regulatory integration of international capital markets has large effects on financial and real outcomes. In the 2000s, the European Union (EU) implemented a policy plan to create a common European market for financial services and capital. Over its implementation, the regulatory integration of international capital markets caused net external financing by publicly traded companies to increase by around $90 \%$. Firms used this additional capital to increase investment and employment.

Studying regulatory changes is challenging, since laws are not passed randomly. For instance, the struggle between the winners and losers of regulatory changes can determine if and when laws are changed (Kroszner and Strahan (1999)). Moreover, regulatory changes can coincide with macroeconomic shocks or trends. A government might, for example, time an unpopular reform so that it coincides with an uptick in the business cycle.

I overcome these identification challenges by exploiting the unique institutional setup of the EU's policy making process. First, I use the bilateral nature of this policy plan. Since regulatory integration between two countries only occurs if both countries have implemented a given law, the proxies for regulatory integration in this paper are based on the bilateral implementation of EU laws. Second, I use the interaction of two staggered sets of events that occur at different institutional levels. The first set of staggered events involves laws passed at the EU level. The second set of staggered events results from European countries individually implementing each of 
these laws within the broad time frame set by the EU for each law. Importantly, I account for potential concerns that the pattern of the staggered implementation of the laws across countries is endogenous by exploiting the bilateral nature of this policy plan. In the 2000s, the EU put forward the Financial Services Action Plan (FSAP) to create a common market for financial services and capital. I focus on the FSAP's most important laws (Slaughter and May (2007), Christensen, Hail, and Leuz (2016), European Commission (2016)): These four "Lamfalussy directives" reduce the regulatory costs of providing financial services across borders, reduce the regulatory costs for the cross-border issuance of securities, harmonize and tighten insider dealing regulation, and harmonize and tighten disclosure provisions. ${ }^{1}$

I illustrate the construction of the baseline index of regulatory integration with three countries and one law (Figure 1). If a country has not implemented a law, its index value is always 0. If a country has implemented a law, I look at the two pairs between this country and the remaining two countries. If the other country in a pair has (not) implemented the law, the index value for this pair is $1(0)$. I average the index values across the two pairs a country is involved in. If no other country has implemented the law, the overall index value is 0 . If one (two) out of the other two countries has (have) implemented this law, the country's index value is 0.5 (1).

This index is the proxy for regulatory integration of international capital markets and is therefore the explanatory variable of interest in the regression analysis. I use a difference-in-differences analysis of a panel data set of publicly traded European companies, which uses the variation in the timing of the implementation of these laws across countries (Figure 2). In addition to firm-level and macroeconomic controls, the setting allows me to include firm fixed effects and year $x$ industry $\times$ European region fixed effects, while clustering standard errors at the country level. This mitigates concerns that unobserved time-invariant differences across firms or time-varying regional differences across industries might drive the results.

The main result is that over its implementation period of approximately five years, regulatory integration of international capital markets led to an increase of around $90 \%$ in net external financing

\footnotetext{
${ }^{1}$ The first two laws are so-called "passporting rights", which are the focus of the debate on the impact of "Brexit" on the United Kingdom's financial sector. For instance, Jamie Dimon, the CEO of JPMorgan Chase \& Co., stated in July 2016: "If we have that passport after Brexit, we likely would not have to make any change at all." "But I think the European Union will not accept that. It will put more conditions on the U.K. and might force banks to become smaller in London." Bloomberg (2016): "Dimon Says Brexit Could Be Reversed as Europe Fixes Region," July 7, http://www.bloomberg.com/news/articles/2016-07-07/jpmorgan-s-dimon-says-not-too-late-to-go-backon-brexit (accessed October 1, 2016).
} 
by companies, when compared to the sample mean of net external financing of five percentage points. Concerning the use of this additional capital, I find increases of $27 \%$ for capital expenditures and $11 \%$ for the number of employees. One reason for the large magnitude of these results is that, at least until the European Sovereign Debt Crisis, the FSAP was the EU's most important policy with respect to financial markets after the introduction of the euro (Altomonte and Nava (2006), Fonteyne (2007)). Furthermore, the particularly large increases in net external financing and capital expenditures concern flow variables with small base levels. Last, cross-sectional tests document that the results are in line with important stylized facts in the data, including, for instance, the credit boom in Southern Europe in the 2000s.

One potential concern is that the preceding results are driven by endogenous implementation timing of the laws, for instance due to lobbying by the financial sector in a country. Thus, I refine the baseline index by only keeping the part of the index that comes from other countries' implementation (Figure 3). I discard the part of the index that is due to the country's own implementation. In the example, if the first country implements the law, nothing changes for this country compared to the original index, because no other country has implemented the law yet. If the second country implements this law, these two out of the three countries are integrated, so the index values of both countries change to 0.5 under the old index. For the refined index, however, only the index value of the country that first implemented the law changes to 0.5 , while for the other country the index value remains at 0 . If the third of the three countries now implements the law, the index value of the "first-mover" country changes to 1 , the index value of the "second-mover" country changes to 0.5 , while the index value of the third country remains at 0 . The refined index of a country therefore does not change when a country itself implements a law, but only when another country does. This alleviates endogeneity concerns with respect to the implementation timing of these laws.

A second potential concern is that countries timed their implementation strategically with respect to other countries, making the countries' implementation order endogenous. To illustrate, one country might front run another country with its implementation timing to provide its financial sector an advantage. I turn to the Group of Seven (G7), which is an informal bloc of industrialized democracies with four members from Europe: France, Germany, Italy and the United Kingdom (UK). The idea is that compared to the rest of Europe, these four countries chose their implementation timing only with respect to other large countries or themselves and not with respect to the 
rest of the EU. However, these large countries are economically and politically important for the remaining countries, since together they accounted for around $70 \%$ of the GDP and population of the EU in 2000 (World Bank (2016b)). I drop all firms from these four large countries from the data set, but still use these countries for the computation of the index. For the index for the remaining countries, I only consider regulatory integration of the remaining countries with the large countries, and not regulatory integration among the smaller countries themselves. Therefore, only regulatory integration of the large countries with the small countries drives the regulatory integration index of the small countries. The motivation is that the implementation timing of the large countries is exogenous for the remaining countries. I also apply the prior refinement so that the index of regulatory integration of a country only changes when other countries implement a law but not when a country itself implements a law. Combining these two refinements alleviates endogeneity concerns about strategic implementation timing of these laws. Reassuringly, the findings persist in both economic and statistical terms for both refinements of the index of regulatory integration.

A third potential concern is that countries experience macroeconomic shocks or trends that coincide with the implementation of the laws. For instance, a country might speed up its implementation of a law if the country's stock market is performing well. Following Rajan and Zingales (1998), the effect of regulatory integration should be stronger for firms in industries that are more dependent on external finance. Thus, I exploit industry variation in the treatment effect. I absorb macroeconomic shocks or trends with year $\times$ country fixed effects. I use these in addition to the standard year $\times$ industry $\times$ European region fixed effects, since the identification comes from the interaction of regulatory integration and external finance dependence. The estimate for the interaction term of regulatory integration and external finance dependence is positive and statistically significant. This result addresses concerns that the implementation timing of the laws coincides with country-level macroeconomic developments.

I also provide evidence on the underlying channels and mechanisms behind the preceding results. First, the previous results on the external finance dependence of industries indicate that an increase in the supply of financing is a potential mechanism for the results.

Second, a decomposition of net external financing into net debt issues and net equity issues shows that an increase in net debt issues drives the overall increase in net external financing.

Third, total financing volume could have remained unchanged, while the increase in financing 
for the firms in the sample could have occurred through a reallocation of financing from firms at the extensive margin through entry or exit. In a country-level analysis of entry, exit, and net entry rates, I do not find evidence that a change in the sample composition of publicly listed companies explains the results.

Fourth, in light of the work by Mundell (1961) on optimum currency areas, one might expect that the effect of regulatory integration of international capital markets on net external financing was stronger within the eurozone than for the rest of Europe. This prediction is supported by the data, which suggests that a common currency facilitates the regulatory integration of international capital markets.

Fifth, in line with the stylized fact of the credit boom in Southern Europe in the 2000s, which was driven by inflows of foreign capital (Hale and Obstfeld (2016)), I find a stronger effect of regulatory integration of international capital markets in Southern Europe. The underlying economic force behind this stronger treatment effect for Southern Europe could have been Southern Europe's lower financial development compared to Northern and Western Europe (La Porta, López de Silanes, Shleifer, and Vishny $(1997,1998))$. Interestingly, Lane (2012) states that the most intensive phase of the credit boom in Southern Europe did not occur after the introduction of the euro in 1999 but during a later period that coincides with the regulatory integration of European capital markets. Lane (2012) also notes that "a complete explanation for the timing of this second, more intense phase of current account deficits and credit booms is still lacking". Based on the evidence in this paper, one might set up the hypothesis that the "second phase" of this credit boom in Southern Europe was fuelled by the regulatory integration of European capital markets.

Besides the aforementioned debate on the geographical scope of financial regulation, I contribute to the literature on law and finance (La Porta, López de Silanes, Shleifer, and Vishny (1997, 1998)). In particular, I add to the nascent work on the relationship between international law and finance (Kalemli-Ozcan, Papaioannou, and Peydró (2010) (the euro's effect on country-level financial integration), Kalemli-Ozcan, Papaioannou, and Peydró (2013) (business cycle synchronization), Christensen, Hail, and Leuz (2016) (stock market liquidity)). Importantly, this is the first paper establishing that the regulatory integration of international capital markets affects firm-level outcomes such as net external financing, investment and employment.

By documenting that this regulatory integration not only increased financial outcomes, but also 
led to expansions in important real variables such as investment or employment, I contribute to the literature on the relationship between financial development and economic growth (King and Levine (1993a,b), Levine (1997), Levine and Zervos (1998), Rajan and Zingales (1998)), which has focused on domestic financial development.

Moreover, there is research that has examined the effects of financial liberalizations (Bekaert and Harvey (2000), Henry (2000), Bekaert, Harvey, and Lundblad (2005)). Financial liberalizations remove restrictions on foreign investments independent of the country from which the investor comes. In contrast, my paper is about the bilateral regulatory integration of countries with no such restrictions for foreign investors. Furthermore, this literature has focused on emerging economies, while I analyze Europe. The similarity between my paper and this body of research are policy changes that make it easier for foreign capital to enter a country.

A parallel also exists with the work on the US banking deregulation (Jayaratne and Strahan (1996), Kroszner and Strahan (1999), Black and Strahan (2002)), which also is about integrating previously separated financial markets. In contrast, this literature studies banking regulation, while my paper studies capital markets regulation. Furthermore, this research stream analyzes explicit restrictions on competition within and across US states, while the policies in my paper harmonize regulations that differ across countries. Last, the setting in my paper is international, in contrast to the focus of this literature on the US.

\section{Institutional Background and Data}

\subsection{The Policy Making Process of the European Union}

The so-called "directives" are a key policy tool of the EU across all policy areas. These directives are passed at the EU level but are implemented by each country individually. Importantly, the member countries of the EU have no choice in whether they implement a directive that has been agreed upon at EU level. For each directive, the EU sets a deadline by which a directive has to be implemented. Using a combination of informal consultations with violating states to address cases that come down to legal uncertainty or misunderstandings, and an infringement procedure, the European Commission successfully achieves compliance of the EU Member States with EU law (Tallberg (2002)). This policy making process guarantees that the same directive is implemented 
across Europe. However, since the national implementation is undertaken by the Member States, there is a staggered implementation pattern which I exploit for identification.

\subsection{The Key of the Financial Services Action Plan: The Lamfalussy Directives}

To study the effects of the regulatory integration of international capital markets, I examine a major policy plan by the EU. While the EU already had a common market for goods and labor at the turn of the millennium, a common market for financial services and capital was lagging behind. The EU therefore put forward the Financial Services Action Plan (FSAP) to create a common market for financial services and capital (European Commission (1999)). The FSAP is the EU's most important policy (at least until the recent financial crisis) with respect to financial markets after the introduction of the euro (Altomonte and Nava (2006), Fonteyne (2007)). The significance of the FSAP is also highlighted by a quote from a publication by the International Monetary Fund:

One of the EU's most comprehensive legal and regulatory endeavors got under way in the form of the Financial Services Action Plan. This undertaking is probably on a par with what the single market meant for cross-border trade in goods. (Fonteyne (2007)).

I focus on the FSAP's most important directives, the four so-called "Lamfalussy directives" (Slaughter and May (2007), Christensen, Hail, and Leuz (2016), European Commission (2016)). These directives are named after Alexandre Lamfalussy who chaired the "Committee of Wise Men on the Regulation of European Securities Markets". The "Lamfalussy directives" include a "single passport" for investment services, a "single passport" to raise capital on a pan-European basis, and two directives that harmonize the regulation and enforcement of the rules on the release of accounting information and on insider dealing. The passporting rights are at the center of the debate on the impact of "Brexit" on the UK's financial sector (see quote in footnote (1)).

The objective of the Directive on Markets in Financial Instruments (MiFID) is the creation of a single market for financial instruments. The key features of this directive can be best explained with an example. Take a UK-based bank that sells a financial security, e.g. a derivative, to a Danish company. Under the old regulatory regime, the UK and Denmark both had their own, different regulations. If both the UK and Denmark have implemented the Directive on Markets in Financial Instruments, the several changes come into play. Both countries now have the same 
regulations governing such cross-border transactions. Furthermore, under the old regime, for all practical purposes, the regulator overseeing such a cross-border transaction was the regulator from the customer's country: in this example Denmark. Under the new regulatory regime, regulatory oversight is transferred to the host country of the bank. Once this regulation is in force across Europe, financial service providers no longer need to satisfy a variety of different and costly regulatory requirements across different European countries. Under the new regime, it thus becomes possible for the bank in the example to have one trading desk based in London focusing on one particular financial instrument that it markets all over Europe. ${ }^{2}$

The Prospectus Directive also includes passporting rights. While the Directive on Markets in Financial Instruments involved passporting rights for financial services providers, the key feature of the Prospectus Directive is that the passport is at the level of individual securities. I illustrate this directive with the prior example. If this Danish firm wanted to issue a corporate bond, it had to satisfy the prospectus requirements of each country in which it wanted to market this bond. Under the Prospectus Directive, it now becomes possible to raise capital on a pan-European basis with one prospectus, or "single passport", that satisfies the new single European prospectus requirements.

The directive on insider dealing and market manipulation, often called the Market Abuse Directive, contains three key features that were harmonized and tightened across the countries involved. First, disclosure rules for inside information aimed at leveling the playing field between insiders and outsiders. Second, ex-post penalties for market manipulation and insider trading. Third, stricter enforcement against violations of the regulations on insider trading and market manipulation. ${ }^{3}$

The Transparency Directive harmonized and tightened transparency regulations for the release of accounting information by companies. This was achieved using a set of disclosure provisions, and requirements concerning the enforcement of these disclosure rules.

\subsection{Data and Sample}

To narrow differences between the treatment group and control group for the difference-in-differences analysis of a panel data set of firm data, I restrict the analysis to European countries. Due to its superior data availability for European firms (Dai (2012)), I rely on Worldscope (Worldscope Funda-

\footnotetext{
${ }^{2}$ See Cumming, Johan, and Li (2011) for an analysis of the effect of MiFID on stock market liquidity.

${ }^{3}$ For the effect of insider trading regulation on the cost of equity see Bhattacharya and Daouk (2002).
} 
mentals Annual and Worldscope Stock Data, both accessed through WRDS). Thus, I am restricted to publicly listed companies. Applying a definition from the United Nations Statistics Division, I divide the 21 countries in the sample into four European regions, which will be important for the definition of the fixed effects. The countries and regions are (Table 1): Northern Europe: Denmark, Finland, Ireland, Norway, Sweden, UK; Western Europe: Austria, Belgium, France, Germany, Luxembourg, Netherlands, Switzerland; Eastern Europe: Czech Republic, Hungary, Poland, Slovakia; Southern Europe: Greece, Italy, Portugal, Spain. The sample starts in 1990 for Northern, Southern and Western Europe. Due to limitations in data coverage the sample starts in 1997 for the four Eastern European countries. The end of the sample period is motivated by evidence in Kalemli-Ozcan, Papaioannou, and Perri (2013). Kalemli-Ozcan, Papaioannou, and Perri document empirically and theoretically that the effect of financial integration on financial flows differs in normal times from crisis times. Therefore, the effect of regulatory integration of international capital markets could also differ across normal times and crisis times. To test for a differential effect, one would however need variation in the regulatory integration of international capital markets in normal times and crisis times. Since the policy plan that I am studying is however implemented before the European Sovereign Debt Crisis, I cannot investigate whether there is such a differential effect so that I end the sample in 2009, i.e. before the onset of the European Sovereign Debt Crisis.

I apply data filters and variable definitions similar to Bris, Koskinen, and Nilsson (2014) (Table 2), who study the firm-level effects of the euro on corporate financing. I exclude financials (e.g. banks, insurance companies, etc.; SIC codes 6000 to 6499) and utilities (SIC codes 4900 to 4949). I also drop American depositary receipts. Furthermore, information on all the data items used needs to be available. Observations with implausible values are excluded, such as firm-years with negative sales or negative total assets. Firm-years with a book value of assets or a stock market capitalization of less than 10 million USD (constant 2014 USD) or 10 or less employees are excluded from the sample. I compute missing values for data items (e.g. total debt), if data entries for the constituents of these data items are available (e.g. short term debt and long term debt). Since the calendar year and the fiscal year of many firms differ, I assign all firm-years whose fiscal year ends in January to March of year t to the calendar year t-1. All other firm-years are assigned to year t. If information on preferred stock, deferred income taxes and investment tax credit, capital expenditures, net proceeds from sale/issue of common and preferred stock, or common/preferred 
stock redeemed, retired or converted is missing, the missing values are set to 0 . Nominal variables (e.g. stock market capitalization) are in USD as provided by Worldscope. Unless these variables are used to construct ratios such as profitability, these variables are deflated with the price index for gross domestic product, as provided by the Bureau of Economic Analysis, to reflect constant 2014 USD. Variable definitions are provided in Table 2. Summary statistics for these data items are provided in Table 3. Unless stated otherwise, the independent variables are lagged one year compared to the dependent variable in the regression specifications.

\section{Empirical Strategy and Results}

\subsection{Regulatory Integration Index}

For the construction of the regulatory integration index I exploit the institutional details of the aforementioned policy making process by the EU. In particular, I use the staggered implementation of EU directives (thereafter referred to as laws) across Europe. Since I am interested in the regulatory integration of international capital markets, the country-specific, time-varying index of regulatory integration is based on the bilateral implementation of EU laws, in contrast to e.g. the unilateral implementation of anti-takeover laws by US states. The idea behind this bilateral notion is that regulatory integration between two countries, for instance through passporting rights, only occurs if both countries have implemented a given policy.

I illustrate the index of regulatory integration with three countries and one law. If a country has not implemented a law, its index value is always 0 . If a country has implemented a law, I look at the two pairs between this country and the remaining two countries. If the other country in a pair has not implemented the law, the index value for this pair is 0 . If both countries in a given pair have implemented the law, the index value for this pair is 1 . I average the two index values across the two pairs to get the index value for the country. If no other country has implemented the law, the overall index value is 0 . If one (two) out of the other two countries has (have) implemented this law, the country's index value is 0.5 (1). For an illustration of the construction of the index see Figure 1. I apply the above procedure to all countries in the sample and all four laws. Therefore, the regulatory integration index ranges from 0 to 4 .

Information on the national implementation dates of these laws, the Lamfalussy laws, is hand- 
collected from various sources, including EU documents, national implementation laws, publications by law firms, and a research tool for legal documents. Every implementation date is verified using two independent sources. I use the implementation dates for these laws to compute the regulatory integration index at the quarterly frequency using the above procedure. Since sufficient coverage of accounting data for European publicly listed companies is only available at the yearly frequency (meaning that the outcome variables and the other independent variables are at the yearly frequency), I compute the yearly average of the regulatory integration index for each country by averaging the quarterly values. I thereby capture the variation in the economic implications of whether a law was, for example, implemented in the first or the last quarter of a given year. I then use the value of the regulatory integration index for a given country in year t-1 as the variable of interest in the analysis of firm-level outcome variables in year t.

Panel A of Figure 2 presents the yearly average of the regulatory integration index, computed by equally weighting the yearly value of the regulatory integration index across the countries implementing the laws in the sample. The average time span between the first country and the last country implementing a law is roughly two years. Importantly, the four laws are not passed by the EU simultaneously. About one law is implemented per year across Europe, over a total time period of four to five years.

Panel B of Figure 2 presents the yearly average of the regulatory integration index for Italy and Spain, two countries in Southern Europe. This figure highlights the differences in the regulatory integration of international capital markets across Europe over time, which are the foundation of the identification strategy.

\subsection{External Finance}

I examine the empirical relation between net external finance, the outcome variable, and the regulatory integration of international capital markets, measured with the regulatory integration index, as defined in the preceding subsection. I employ a difference-in-differences analysis of a panel data set of publicly listed European companies that uses the variation in the implementation timing of the laws across countries for identification. I include firm fixed effects to account for time-invariant firm unobservables. Since the data indicates that (publicly listed) European firms are not changing their legal incorporation across countries, the firm fixed effects are also controlling for any time-invariant 
country unobservables. I include year $\times$ industry $\times$ European region fixed effects to control for unobserved differences across firms due to industry conditions in a European region in a given year. Industry is defined at the 3-digit SIC code level and I have divided Europe into four regions (see Table 1). Note that I cannot control for country $\times$ year fixed effects, since the variable of interest, the regulatory integration index, varies at the country-year level. I cluster standard errors at the country level, since there might be time-series and cross-sectional correlation of observations within a given country. All regressions in the paper are estimated with the "reghdfe" Stata package (Correia (2016)), which provides fast estimation of regression models with more than one set of high-dimensional fixed effects.

I also include macroeconomic and firm-level controls. For variable definitions see Table 2. For summary statistics see Table 3. One important macroeconomic factor is whether a country has its own currency or whether it is part of a currency union. For instance, about two thirds of the countries in the sample join the euro currency area during the sample period. To account for these differences in currency regimes, I control for the coarse currency regime classification by Ilzetzki, Reinhart, and Rogoff (2011). A value of 1 in the coarse currency regime classification stands for currency unions and tight currency pegs. A value of 4 for this variable stands for a freely floating currency. In addition, I include a dummy variable that switches from 0 to 1 at the time a country joins the European Union during the sample period, thereby capturing potential changes for these countries due to EU membership. To account for general macroeconomic developments, I control for real GDP growth and inflation at the country level. Since the outcome variable is measured in year t, while the independent variables are measured in year t-1 to avoid any mechanical relationship, I control both for real GDP growth and for inflation in year t and year t-1 in a given country.

To control for differences in investment opportunities, I control for Tobin's Q and sales growth. To control for differences in profitability, I include EBITDA over total assets. To control for potential borrowing constraints of firms, I employ market leverage. Since the ability of firms to access external financing might be affected by their ability to provide collateral, I control for the ratio of collateral (net property, plant and equipment plus inventory) to total assets. To adjust for potential differences in the need to access external finance, I control for cash holdings. Lastly, to control for potential differences associated with firm size, I control for the natural logarithm of stock market capitalization in constant 2014 USD. 
Table 4 contains the results for the regression of net external finance on the above variables. In model 1 of the table, I only include the regulatory integration index and year fixed effects. The point estimate of the index is 1.30 percentage points, with a p-value of $0 \%$. In model 2 , I add firm-level and macroeconomic control variables, and the point estimate for the index increases slightly to 1.43 percentage points, while the p-value remains at $0 \%$. In model 3 , I additionally control for firm fixed effects. The magnitude of the coefficient of the index decreases to 1.06 percentage points, with a p-value of $0 \%$. In model 4 , I replace year fixed effects with year $\times$ industry effects, which results in a point estimate of the index of 0.83 percentage points (p-value of $0 \%$ ). In model 5 , the tightest specification, I replace year $\times$ industry fixed effects with year $\times$ industry $\times$ European region fixed effects. The point estimate of the index is 1.14 percentage points, with a p-value of $0 \%$.

Regarding the economic significance, the point estimate of 1.14 for the regulatory integration index in model 5 implies that if all countries in the sample implement 1 law, net external finance by the companies in these countries increases by 1.14 percentage points. If all countries in the sample implement all 4 laws, the effect on net external financing for the firms from these countries is four times this point estimate. Thus, the economic magnitude of this effect is large. Given the sample average of 4.97 percentage points of net external finance, if all countries in the sample implement one law, net external finance by the companies in these countries increases by $23 \%$. If all countries implement all laws, net external finance increases by $92 \%$.

There are several reasons why the magnitude of the results are reasonable. First, at least until the European Sovereign Debt Crisis, the FSAP was the EU's most important policy with respect to financial markets after the introduction of the euro (Altomonte and Nava (2006), Fonteyne (2007)). As a consequence, an important policy plan might result in large changes in related outcome variables. Second, while the preceding results are large in relative terms, they concern a flow variable with a small absolute level. Third, cross-sectional tests discussed in later sections of the paper document that the results are in line with several stylized facts in the data, including, for instance, the credit boom in Southern Europe in the 2000s.

The point estimates of the control variables have the expected signs, except for the significantly negative point estimate for the EU Accession dummy. This can be explained by bankruptcy and collateral reforms the Eastern European countries in the sample undertook before they joined the EU. These reforms were externally imposed on them as part of the conditions that they had to 
fulfill to meet the entry requirements for the European Union. ${ }^{4}$ Therefore, the macroeconomic conditions in Eastern Europe for raising external capital before these countries joined the EU were much more attractive than their macroeconomic variables such as real GDP growth would suggest. This "unobserved" ease of raising net external finance in these countries before they joined the EU therefore explains the negative point estimate for the EU Accession dummy. Moreover, the point estimates for the EU Accession dummy in separate analyses of net debt issues and net equity issues indicate that the negative point estimate for the EU Accession dummy is entirely driven by net debt issues, which is in line with the preceding result and bankruptcy and collateral reforms being more important for debt than equity.

The economic magnitudes of the point estimates of the control variables also seem plausible. For instance, if one moves from the 25th to the 75 th percentile for Tobin's Q net external finance increases by 3.48 percentage points. For market leverage a one standard deviation increase results in a reduction of net external finance of more than 9 percentage points. In contrast, the same one standard deviation change in market leverage results in a reduction of net external finance of only one percentage point, when computed with the point estimate for market leverage from model 2 , which does not include firm fixed effects. This highlights the importance of controlling for time invariant firm unobservables by including firm fixed effects.

\subsection{Real Effects: The Use of the Additional Financing}

Having established that the regulatory integration of international capital markets leads to an increase in net external finance, a natural question is whether there are any real effects concerning the use of this additional financing. I analyze these real effects by using the same research design as in the tightest specification when analyzing the relation between net external finance and regulatory integration (model 5 of Table 4). In model 1 of Table 5 , I investigate whether the regulatory integration of international capital markets affects investment. The dependent variable is the investment rate, which is defined as capital expenditures in the current year over total assets in the preceding year. I find that if all countries implement one law (out of the total of four), the investment rate increases by 0.43 percentage points (p-value $0 \%$ ), which corresponds to an increase of 6.77 percent relative to the average investment rate of 6.35 percentage points in the sample. I also investigate

\footnotetext{
${ }^{4}$ Haselmann, Pistor, and Vig (2010) study these externally imposed reforms in Eastern Europe.
} 
whether the regulatory integration of international capital markets affects firm-level employment, by using the natural logarithm of the number of employees, winsorized at the $5 \%$ level at both sides of the distribution, as the dependent variable in model 2 of Table $5 .^{5}$ I document that if all countries implement one law, employment increases by 2.65 percent, with the result being highly statistically significant (p-value 5\%).

Since net external financing and the investment rate are flow variables which are computed by dividing by book assets, their magnitudes can be directly related. Nearly $40 \%$ of the increase in net external financing is invested in capital expenditures. Since the number of employees is a stock variable, no direct statement about the use of the remaining $60 \%$ of the additional capital can be made, but it appears reasonable to conjecture that the remaining financing is spent to increase the workforce.

\subsection{Endogeneity in the Timing of the Implementation Dates}

While there is evidence that the timing of the national implementation of EU laws is generally driven by lengthy and inflexible legislative procedures ${ }^{6}$ (and in the case of these four laws, the Lamfalussy directives, due to their complexity, also by the time needed to set up new supervisory authorities), ${ }^{7}$ it is still possible that the timing of a country's decision to implement a given law is endogenous. To address this concern, I create the "Regulatory Integration Takeout" index, in which I only keep the part of the index that comes from other countries' implementation and discard the part of the index that is due to the country's own implementation.

I use the prior example of three countries and one law to illustrate the construction of this refined index of regulatory integration. If the first country implements the law, nothing changes for this country compared to the original index, because no other country has yet implemented the law. If the second country implements this law, these two out of the three countries are integrated so that the index values of both countries change to 0.5 under the old index. For the refined "Regulatory Integration Takeout" index, however, only the index value of the country that first

\footnotetext{
${ }^{5}$ In model 2, where the dependent variable is $\log$ (employees), I do not control for firm size to avoid a mechanical relationship with the dependent variable.

${ }^{6}$ Knill and Lenschow (1998), Tallberg (2002), Börzel, Hofmann, Panke, and Sprungk (2010). The legislative procedures include the drafting of national implementation laws, consultation periods, multiple readings in the chambers of national parliaments, signing by the head of state, and the public notification of the national implementation law.

${ }^{7}$ Kalemli-Ozcan, Papaioannou, and Peydró (2010, 2013), Christensen, Hail, and Leuz (2016), Bloomfield, Bruggemann, Christensen, and Leuz (2016).
} 
implemented the law changes to 0.5 , while for the other country the index value remains 0 , which highlights that this refined index is constructed in an asymmetric manner. If the last of the three countries implements the law, the index value of the "first-mover" country changes to 1 , the index value of the "second-mover" country changes to 0.5 , while the index value of the third country remains 0 . The "Regulatory Integration Takeout" index of a given country is therefore driven only by other countries' implementation timing, and not by the country's own implementation timing. This alleviates endogeneity concerns with respect to the implementation timing.

For an illustration of the construction of the index see Figure 3. I apply the methodology of the regulatory integration takeout index to all countries in the sample and all four laws. Since I discard the effect of the regulatory integration on the late adopters' index values, this refined index cannot reach the value 4 for all countries. In model 1 of Table 6 , I use the regulatory integration takeout index as the variable of interest, while otherwise using the same regression framework as before. The point estimate for the regulatory integration takeout index is 1.41 percentage points (p-value $0 \%$ ), which suggests that the relationship between regulatory integration and net external financing is robust to accounting for the previously mentioned endogeneity concerns.

\subsection{Strategic Implementation Timing}

A further concern is that countries time their implementation strategically with respect to other countries, making countries' implementation order endogenous. To address this concern, I create the "Regulatory Integration Takeout Big 4" index. I turn to the Group of Seven (G7), which is an informal bloc of industrialized democracies. The G7 has four European members which I define as large countries: France, Germany, Italy and the UK (see Table 1). The idea is that compared to the rest of Europe, these four countries have chosen their implementation timing only with respect to other large countries or themselves, and not with respect to the rest of the EU, since these large countries do not take the remaining countries into account. If, for instance, Germany were to strategically time its implementation of a given law, the assumption is that only domestic issues in Germany and the corresponding issues in France, Italy and the UK would affect the German implementation timing, but not, for instance, domestic issues in Denmark. However, these large countries are economically and politically important for the remaining countries, since together they accounted for $72 \%$ of the GDP and $68 \%$ of the population of the EU in 2000 (World Bank 
(2016b)). I drop all firms from these four countries from the data set, but still use these countries for the computation of the index. For the remaining countries, I only consider regulatory integration of the remaining countries with the large countries, and not regulatory integration among the remaining countries themselves. To illustrate, the idea is that for a small country such as Finland, regulatory integration with the UK or Germany is important while regulatory integration with, for instance, Austria is less important. Therefore, only regulatory integration of the large countries with the remaining countries drives the regulatory integration index of the remaining countries. The motivation is that the implementation timing of the large countries is exogenous for the remaining countries. In addition, I also apply the prior refinement from the "Regulatory Integration Takeout" index for the "Regulatory Integration Takeout Big 4", so that the timing of when a country itself implements a law does not affect its index value. Taken together, these two refinements therefore address the endogeneity of the implementation timing and of countries' strategic implementation timing with respect to each other.

I explain the construction of the "Regulatory Integration Takeout Big 4" index. To fully illustrate all features of this refined index of regulatory integration, I need to extend the preceding example from three to four countries. Imagine that two out of these four countries are large countries. I drop the firms from the two large countries from the sample and only use the two large countries for the computation of the index. Take one of the two small countries. For this small country, I only consider the two links it has with the two large countries, and not the one with the other small country. So for this small country, possible index values are $0,0.5$ and 1 . Taking, for example, Sweden, its index of regulatory integration is now only driven by the country-pairs that it forms with the four large countries, but not with other small countries such as Portugal or Greece. I also apply the prior refinement of not taking into account the effect of the country's own implementation on its index value. If the country implements the law after both large countries, its index remains 0 . If it implements the law after one large country but before the other, its index is capped at 0.5 . Only if the small country implements the law before the two large countries can its index reach 1 .

For an illustration of the construction of the index see Figure 4. I apply the methodology of the "Regulatory Integration Takeout Big 4" index to all countries in the sample and all four laws. In models 2 to 4 of Table 6 , I examine the effect of regulatory integration of international capital 
markets on net external finance. First, note that firms from France, Germany, Italy, and the UK are now excluded from the sample. In model 2 of Table 6, I use the standard regulatory integration index for this smaller sample and find a point estimate of 1.59 percentage points, with a p-value of $2 \%$. Next, I apply the regulatory integration takeout index from the prior subsection to this sample in model 3 of Table 6 . The point estimate for the regulatory integration takeout index is 2.96 percentage points with a p-value of $0 \%$. The point estimate for the regulatory integration takeout index increases compared to the regulatory integration index. The reason is that while the changes in the dependent variable caused by the regulatory integration of international capital markets remain the same, the changes in the values of the refined index are smaller than the ones in the original index, which results in a larger point estimate. In model 4 of Table 6 , I apply the "Regulatory Integration Takeout Big 4" index. The point estimate for this variable is 2.93 percentage points, with a p-value of $0 \%$.

\subsection{Macroeconomic Shocks or Trends}

I address the concern that countries experience macroeconomic shocks or time trends that are coinciding with the timing of the implementation of the laws. Crucially, the pattern of these shocks or time trends also needs to explain the two refined indexes, which already raises the bar for any alternative explanation. Following the paper by Rajan and Zingales (1998) on external finance dependence, the treatment effect of regulatory integration should be stronger for firms in industries that are more dependent on external finance. Using Worldscope data for publicly traded companies, I construct a proxy for external finance dependence for three-digit SIC code industries in Europe following Rajan and Zingales (1998). I use the sample and data filters used to construct the main sample in the paper, with the following exceptions: As in Rajan and Zingales (1998) the sample for the construction of the external finance dependence measure starts in 1980. To avoid that the sample used for the construction of this proxy is influenced by changes in financial integration in Europe, I end the sample in 1998, the year before the introduction of the euro, which marks the first wave of financial integration in Europe during the sample period. To reduce the influence of outliers, I require that a firm has an aggregate of 10 million USD (in constant 2014 USD) of capital expenditures over all years it is listed in Worldscope. Furthermore, I only compute the measure of external finance dependence for those industries that during the sample years used for 
the construction of the external finance dependence measure have at least a total of 5 different firms. Since I want to interact this proxy of external finance dependence with the regulatory integration index, I standardize the proxy so that it ranges from 0 to 1 . As the proxy of external finance dependence is time-invariant, its main effect on external finance dependence is absorbed by the firm fixed effects.

In Table 7, I provide two estimates on how regulatory integration interacts with external finance dependence. In model 1 , I include year $\times$ industry fixed effects. In model 2 , I include year $\times$ industry $\times$ region fixed effects. In addition, I include firm fixed effects and, importantly, year $\times$ country fixed effects in both specifications. The year $\times$ country fixed effects absorb any macro shocks or time trends at the country level, while year $\times$ industry $(\times$ region $)$ fixed effects absorb Europe (European-region) wide industry shocks. The positive and significant point estimates for the interaction of regulatory integration and external finance dependence lead to the conclusion that the results are robust to macroeconomic shocks or trends.

\section{Channels}

\subsection{Net Debt Issues and Net Equity Issues}

I provide evidence on the channels beneath the effect of regulatory integration of international capital markets on net external financing. First, I decompose net external financing into its components - net debt issues and net equity issues - using otherwise the same regression specification as in model 5 of Table 4 . The point estimates for net debt issues and net equity issues are 1.03 and 0.07 percentage points, with p-values of $0 \%$ and $60 \%$ (models 1 and 2 of Table 8 ). Thus, the overall increase in net external financing is driven by net debt issues.

\subsection{Sample Composition of Publicly Listed Companies}

One channel for the results could be that the total financing volume in Europe has been unchanged, while regulatory integration caused a reallocation of financing among publicly listed companies. In particular, it could be that while on the one hand the financing provided to the companies in the sample increased (as documented earlier in this paper), on the other hand the financing for publicly listed companies not in the sample decreased by the same aggregate amount, leaving the 
total financing volume unchanged. Such a shift in the allocation of financing can occur through changes on the extensive margin concerning the firms that are part of the sample. Such changes can occur through entries (initial public offerings, hereafter IPOs) and exits (delistings, whether through bankruptcy, takeovers or going private).

One challenge in analyzing whether changes in the sample composition through entries or exits drive the results is that I do not observe the entries or exits that do not occur. Consequently, this channel cannot be studied at the firm level. Due to the relatively low number of entries and exits of publicly listed firms at the industry level even in large economies such as Germany, I address this concern by studying country-level changes in entry and exit. Since the absolute number of entries and exits needs to be examined in relation to the number of firms in a country, I study entry and exit rates. These rates are defined as the number of firms that enter (exit) the sample through IPO (delisting) in a given country in a given year t, divided by the number of publicly listed firms in the same country in year t-1. I also compute the net entry rate, which is the difference between the entry rate and the exit rate. The data on IPOs are from the Thomson Reuters SDC Platinum's database on New Issues. ${ }^{8}$ I apply data filters for IPOs for the SDC Platinum database in line with Doidge, Karolyi, and Stulz (2013). Since there is no reason to believe that Worldscope stops covering firms that it has covered in the past without the firm having exited the sample through exactly one of the ways that I want to capture, I use the last year a firm appears in Worldscope as the firm's exit year.

I then use the entry rate, exit rate and net entry rate as the outcome variables in a countrylevel analysis of potential changes in the sample composition. The variable of interest is, as before, the regulatory integration index. I include country and year $\times$ European region fixed effects and cluster at the country level. I include the same country-level macroeconomic controls as in the firm-level analysis. I employ this research design in Models 1 (entry), 3 (exit) and 5 (net entry) of Table 9. Since one of the well established stylized facts from the IPO literature (see Ritter and Welch (2002) for a review) is the high cyclicality of IPOs, I control for macro determinants of IPO activity identified by Lowry (2003): the stock market return in a country, the stock price volatility

\footnotetext{
${ }^{8}$ I turn to IPO data from SDC Platinum to identify entries, because even Worldscope with its superior coverage of European firms (Dai (2012)) undersamples publicly listed companies. Importantly, the coverage in Europe improves for the late 1990s and the early 2000s. Relying on the first time a firm appears in the Worldscope data to indicate the date a company goes public would therefore overestimate the actual number of IPOs occurring.
} 
in a country, and the q ratio of the stocks in a country. Data on the average stock market return and average stock price volatility based on the national stock market indexes are from the Global Financial Development database from the World Bank (2016a). To avoid large outliers, I compute the median q ratio in a country using Worldscope data. As for the other macro controls used in the paper, I control for the values of these IPO controls in the years t and t-1. In Models 2 (entry), 4 (exit), and 5 (net entry) of Table 9, I employ the above research design while additionally controlling for those variables shown to be important in the IPO literature.

The results in Table 9 suggest that the effect of regulatory integration on the outcome variables is not statistically significant, which implies that a reallocation of financing among publicly listed companies is a less likely channel.

\subsection{Euro Currency Union and European Regions}

Next, I examine whether the effect of regulatory integration differs across eurozone and non-eurozone countries in Europe. If the effect of regulatory integration is larger in the eurozone than in the rest of Europe, this hints that a common currency facilitates regulatory integration of international capital markets. Examining such a potential heterogeneous treatment effect is important, since Mundell's seminal work on optimal currency areas (Mundell (1961)) suggests that the free movement of capital within a currency area is a prerequisite for the functioning of a currency union. In addition, a large number of studies shows that the introduction of the euro led to an increase in international capital flows across the associated countries (see, for instance, Lane and Milesi-Ferretti (2007), Hale and Obstfeld (2016); for a survey see Lane (2006)). Last, Kalemli-Ozcan, Papaioannou, and Peydró (2010) document that regulatory integration through the FSAP was one of the three factors underlying the euro's effect on country-level financial integration.

To test for a differential treatment effect for euro-currency and non euro-currency countries, I include the regulatory integration index, and an interaction effect of the index with a euro-currency dummy in the regression. In Model 1 of Table 10, the main effect of regulatory integration on net external finance is 0.47 percentage points ( $\mathrm{p}$-value $3 \%$ ), while the additional effect of regulatory integration for the euro countries is 0.63 percentage points (p-value 0\%). This suggests that a common currency facilitates the regulatory integration of international capital markets. ${ }^{9}$

\footnotetext{
${ }^{9}$ While the cross-sectional results for individual countries hold with year $\times$ region $\times$ industry fixed effects, I include
} 
An important stylized fact is the credit boom in Southern Europe in the 2000s, which was driven by inflows of foreign capital and which burst during the European sovereign debt crisis (see, for instance, Lane (2012), Hale and Obstfeld (2016)). Therefore, I study whether there is a heterogeneous treatment effect of regulatory integration on net external finance in Southern Europe compared to the rest of Europe. In Model 2 of Table 10, I find that the main effect of regulatory integration is 0.79 percentage points (p-value 0\%), while the additional effect for Southern Europe is 1.13 percentage points (p-value 0\%). In Model 3 of Table 10 I disentangle the treatment effect for Southern Europe into separate point estimates for its constituent countries: Portugal (0.07 percentage points, p-value $79 \%)$, Italy (0.86 percentage points, p-value $0 \%)$, Greece (1.63 percentage points, p-value 0\%), and Spain (0.95 percentage points, p-value 1\%). The main effect of regulatory integration to which these country specific effects need to be added is 0.77 percentage points ( $\mathrm{p}$-value $0 \%$ ). These findings are in line with the stylized facts on the credit boom in Southern Europe in the 2000s and the recent sovereign debt crisis in these countries, in particular Greece. Interestingly, the point estimate for Greece in Model 3 is significantly different from the point estimates for Italy and Portugal at the $1 \%$ level and from the point estimate for Spain at the $5 \%$ level.

Lane (2012) states that the most intensive phase of the credit boom in Southern Europe did not occur after the introduction of the euro in 1999 but during a later period that coincides with the regulatory integration of European capital markets. Lane (2012) also notes that "a complete explanation for the timing of this second, more intense phase of current account deficits and credit booms is still lacking". Based on the evidence in this paper, one might set up the hypothesis that the "second phase" of this credit boom in Southern Europe was fuelled by the regulatory integration of European capital markets.

Since the four Southern European countries are all in the eurozone, I investigate whether the additional effect of regulatory integration for the eurozone is driven by the effect for Southern Europe or whether these are two independent effects. I decompose Regulatory Integration $\times$ Euro into Regulatory Integration $\times$ South and Regulatory Integration $\times$ Euro Not South. In Model 4 of

year $\times$ industry fixed effects in all specifications in which I study heterogeneous effects across different countries. When investigating whether there is a heterogeneous effect for an entire region of Europe, I cannot include region based fixed effects. As a consequence, I would have to include different fixed effects depending on whether I investigate the results for a European region or individual countries within this region, making a comparison of the point estimates difficult. Furthermore, the more natural comparison for how a given country is performing within Europe is against the average effect for Europe, and not how it is performing against the the average effect for a given European region. 
Table 10, I find that the main effect for the regulatory integration index is 0.56 percentage points (pvalue $0 \%$ ), while the point estimates for Regulatory integration $\times$ South and Regulatory Integration $\times$ Euro Not South are 1.37 percentage points (p-value $0 \%$ ) and 0.42 percentage points (p-value 1\%). This suggests that the "eurozone" effect is not purely a "Southern Europe" effect.

Last, I provide additional evidence for heterogeneous treatment effects across different European regions. In Model 5 of Table 10, I replace the main effect for regulatory integration with separate estimates for the four regions of Europe in the sample. Regulatory Integration $\times$ North has a point estimate of 0.70 percentage points. Regulatory Integration $\times$ West has a point estimate of 0.94 percentage points. Regulatory Integration $\times$ South has a point estimate of 1.98 percentage points and Regulatory Integration $\times$ East has a point estimate of 2.28. All 4 estimates are significant at the $1 \%$ level. The estimate for Southern Europe is significantly different at the $1 \%$ level from the estimates for both Northern and Western Europe. The estimate for Eastern Europe is significantly different at the $5 \%$ level from the one for Northern Europe and the $10 \%$ level from the one for Western Europe. The lower statistical significance of the t-tests for Eastern Europe can be explained with the fact that only 1.2 percent of the firm-years in the sample are from Eastern Europe. In line with prior results, these findings suggest that there was a particularly strong treatment effect in Southern Europe. The strongest effect was however in the developing economies of Eastern Europe. The underlying economic force behind these strong treatment effects in Eastern and Southern Europe could have been their lower financial development compared to Northern and Western Europe (La Porta, López de Silanes, Shleifer, and Vishny $(1997,1998))$.

\section{Conclusion}

I study the financial and real effects of regulatory integration of international capital markets. I exploit a unique policy plan by the EU, which created a common European market for financial services and capital. I use a novel empirical approach to overcome the challenges inherent in studying regulatory changes by exploiting the bilateral and staggered nature of European laws that reduced the regulatory costs of engaging in cross-border financial services. Importantly, I account for potential concerns that the pattern of the staggered implementation of the laws across countries is endogenous by exploiting the bilateral nature of these laws. 
Over the course of its implementation, regulatory integration of international capital markets causes large increases in external financing, investment and employment by publicly listed European companies. Thereby, I document that an increase of the size of the regulatory area by integrating national markets into a common market across countries can lead to large increases in important financial and real outcome variables. Thus, the paper contributes to the debate on the regulatory area of financial regulation. In addition, I also add to the literature on law and finance (La Porta, López de Silanes, Shleifer, and Vishny $(1997,1998)$ ), which has focused on domestic law, while this paper is about international law.

In light of the large effects of regulatory integration of international capital markets on net external financing, investment and employment, one should note that policy makers and academics are thinking about ways to stimulate the real economy in Europe after the recent financial crisis. A lot of attention is paid to the unconventional monetary policy by the European Central Bank, and a large number of academic papers are investigating the real effects of the unconventional monetary policy in Europe, the US, and elsewhere. ${ }^{10}$ In contrast, regulatory policies by the EU that are meant to stimulate growth have received relatively little attention. For instance, in 2015, the EU proposed an action plan on a capital markets union (European Commission (2015)). Building upon the policy plan studied in this paper, the idea of this action plan is to deepen the integration of European capital markets even further. With the capital markets union, the EU aims to promote investment, employment and economic growth by increasing the supply of financing. Considering the large real effects of regulatory integration documented in this paper, regulatory policies like the action plan on a capital markets union deserve more attention.

\section{References}

Altomonte, C., and M. Nava (2006): Economics and Policies of an Enlarged Europe. Edward Elgar Publishing, Cheltenham, UK and Northampton, MA, USA.

Bebchuk, L. A. (1992): "Federalism and the Corporation: The Desirable Limits on State Competition in Corporate Law," Harvard Law Review, 105(7), 1435-1510.

Bekaert, G., and C. R. Harvey (2000): "Foreign Speculators and Emerging Equity Markets," Journal of Finance, 55(2), 565-613.

Bekaert, G., C. R. Harvey, and C. Lundblad (2005): "Does Financial Liberalization Spur Growth?," Journal of Financial Economics, 77(1), 3-55.

Bhattacharya, U., and H. Daouk (2002): "The World Price of Insider Trading," Journal of Finance, 57(1), 75-108.

\footnotetext{
${ }^{10}$ See, e.g., Chakraborty, Goldstein, and MacKinlay (2017), Krishnamurthy, Nagel, and Vissing-Jorgensen (2017).
} 
Black, S. E., And P. E. Strahan (2002): "Entrepreneurship and Bank Credit Availability," Journal of Finance, 57(6), 2807-2833.

Bloomfield, M. J., U. Bruggemann, H. B. Christensen, and C. Leuz (2016): "The Effect of Regulatory Harmonization on Cross-Border Labor Migration: Evidence from the Accounting Profession," Journal of Accounting Research, forthcoming.

Börzel, T. A., T. Hofmann, D. Panke, and C. Sprungk (2010): "Obstinate and Inefficient: Why Member States Do Not Comply With European Law," Comparative Political Studies, 43(11), $1363-1390$.

Bris, A., Y. Koskinen, and M. Nilsson (2014): "The Euro and Corporate Financing Before the Crisis," Journal of Financial Economics, 114(3), 554-575.

Chakraborty, I., I. Goldstein, and A. MacKinlay (2017): "Monetary Stimulus and Bank Lending," Working Paper. University of Miami, University of Pennsylvania and Virginia Tech.

Christensen, H., L. Hail, and C. Leuz (2016): "Capital-Market Effects of Securities Regulation. Prior Conditions, Implementation, and Enforcement," Review of Financial Studies, 29(11), 28852924.

Coffee JR., J. C. (2002): "Racing Towards the Top?: The Impact of Cross-Listings and Stock Market Competition on International Corporate Governance," Columbia Law Review, 102(7), $1757-1831$.

Correia, S. (2016): "A Feasible Estimator for Linear Models with Multi-Way Fixed Effects," Working Paper. Duke University.

Cumming, D., S. Johan, and D. Li (2011): "Exchange Trading Rules and Stock Market Liquidity," Journal of Financial Economics, 99(3), 651-671.

DAI, R. (2012): "International Accounting Databases on WRDS: Comparative Analysis," Working Paper. University of Pennsylvania.

Doidge, C., G. A. Karolyi, and R. M. Stulz (2013): "The U.S. Left Behind? Financial Globalization and the Rise of IPOs Outside the U.S.," Journal of Financial Economics, 110(3), $546-573$.

European Commission (1999): Financial Services: Building a Framework for Action. European Commission, Brussels.

(2015): Action Plan on Building a Capital Markets Union. European Commission, Brussels.

(2016): "Transposition of Lamfalussy Directives - European Commission," http://ec.europa.eu/finance/securities/lamfalussy/transposition/index_en.htm (accessed October 1, 2016).

Fonteyne, W. (2007): "Toward a Single Financial Market," in Integrating Europe's Financial Markets, ed. by J. Decressin, H. Faruqee, and W. Fonteyne, chap. 1, pp. 1-16. International Monetary Fund, Washington, D.C.

Hale, G., And M. Obstfeld (2016): "The Euro and the Geography of International Debt Flows," Journal of the European Economic Association, 14(1), 115-144.

Haselmann, R., K. Pistor, And V. Vig (2010): "How Law Affects Lending," Review of Financial Studies, 23(2), 549-580.

Henry, P. B. (2000): "Stock Market Liberalization, Economic Reform, and Emerging Market Equity Prices," Journal of Finance, 55(2), 529-564.

Houston, J. F., C. Lin, and Y. Ma (2012): "Regulatory Arbitrage and International Bank Flows," Journal of Finance, 67(5), 1845-1895.

Ilzetzki, E., C. M. Reinhart, and K. S. Rogoff (2011): "The Country Chronologies and Background Material to Exchange Rate Arrangements into the 21st Century: Will the Anchor Currency Hold?," Working Paper. London School of Economics, University of Maryland and Harvard University. 
International Monetary Fund (2015): "World Economic Outlook Database," http://www.imf.org/external/pubs/ft/weo/2015/02/weodata/download.aspx (accessed October 15, 2016).

Jayaratne, J., and P. E. Strahan (1996): "The Finance-Growth Nexus: Evidence from Bank Branch Deregulation," Quarterly Journal of Economics, 111(3), 639-670.

Kalemli-Ozcan, S., E. Papaioannou, and F. Perri (2013): "Global Banks and Crisis Transmission," Journal of International Economics, 89(2), 495-510.

Kalemli-Ozcan, S., E. Papaioannou, and J.-L. Peydró (2010): "What Lies Beneath the Euro's Effect on Financial Integration? Currency Risk, Legal Harmonization, or Trade?," Journal of International Economics, 81(1), 75-88.

(2013): "Financial Regulation, Financial Globalization, and the Synchronization of Economic Activity," Journal of Finance, 68(3), 1179-1228.

Karolyi, G. A., and A. G. Taboada (2015): "Regulatory Arbitrage and Cross-Border Bank Acquisitions," Journal of Finance, 70(6), 2395-2450.

King, R. G., And R. Levine (1993a): "Finance and Growth: Schumpeter Might be Right," Quarterly Journal of Economics, 108(3), 717-737.

(1993b): "Finance, Entrepreneurship and Growth: Theory and Evidence," Journal of Monetary Economics, 32(3), 513-542.

Knill, C., And A. Lenschow (1998): "Coping with Europe: The Impact of British and German Administrations on the Implementation of EU Environmental Policy," Journal of European Public Policy, 5(4), 595-614.

Krishnamurthy, A., S. Nagel, and A. Vissing-Jorgensen (2017): "ECB Policies Involving Government Bond Purchases: Impact and Channels," Working Paper. Stanford University, University of Michigan and University of California Berkeley.

Kroszner, R. S., and P. E. Strahan (1999): "What Drives Deregulation? Economics and Politics of the Relaxation of Bank Branching Restrictions," Quarterly Journal of Economics, 114(4), 1437-1467.

La Porta, R., F. López de Silanes, A. Shleifer, and R. Vishny (1997): "Legal Determinants of External Finance," Journal of Finance, 52(3), 1131-1150.

(1998): "Law and Finance," Journal of Political Economy, 106(6), 1113-1155.

Lane, P. R. (2006): "The Real Effects of European Monetary Union," Journal of Economic Perspectives, 20(4), 47-66.

(2012): "The European Sovereign Debt Crisis," Journal of Economic Perspectives, 26(3), $49-67$.

Lane, P. R., And G. M. Milesi-Ferretti (2007): "The External Wealth of Nations Mark II: Revised and Extended Estimates of Foreign Assets and Liabilities, 1970-2004," Journal of International Economics, 73(2), 223-250.

Levine, R. (1997): "Financial Development and Economic Growth: Views and Agenda," Journal of Economic Literature, 35(2), 688-726.

Levine, R., And S. Zervos (1998): "Stock Markets, Banks, and Economic Growth," American Economic Review, 88(3), 537-558.

Lowry, M. (2003): "Why Does IPO Volume Fluctuate So Much?," Journal of Financial Economics, 67(1), 3-40.

Mundell, R. A. (1961): "A Theory of Optimum Currency Areas," American Economic Review, 51(4), 657-665.

Rajan, R. G., and L. Zingales (1998): "Financial Dependence and Growth," American Economic Review, 88(3), 559-586.

Revesz, R. L. (1992): "Rehabilitating Interstate Competition: Rethinking the Race-to-the-Bottom 
Rationale for Federal Environmental Regulation," New York University Law Review, 67(1), 12101254.

Ritter, J. R., And I. Welch (2002): "A Review of IPO Activity, Pricing, and Allocations," Journal of Finance, 57(4), 1795-1828.

Slaughter And May (2007): The Markets in Financial Instruments Directive and the Single European Market in Investment Services. Slaughter and May, London, 3 edn.

Stiglitz, J. E. (2002): Globalization and Its Discontents. Allen Lane Penguin Press, London.

Tallberg, J. (2002): "Paths to Compliance: Enforcement, Management, and the European Union," International Organization, 56(3), 609-643.

World BANK (2016a): "Global Financial Development Database," http://data.worldbank.org/data-catalog/global-financial-development (accessed October 16, 2016).

(2016b): "World Development Indicators. Data File," http://data.worldbank.org/datacatalog/world-development-indicators (accessed October 15, 2016). 


\section{Figure 1: Regulatory Integration Index}

This figure illustrates the regulatory integration index with three countries and one law (for detail see Subsection 3.1). Changes in the contemporaneous (preceding) time period(s) are represented with dashed (solid) circles, arrows or bars.

\section{Panel A: Regulatory Integration Index at $\mathrm{t}=\mathbf{1}$}

A implements the law at $t=1$. Its index value is 0 , because the other countries have not implemented the law yet.

$$
\mathrm{C}_{t=1} \mathrm{~B}_{t=2}
$$$$
\text { Regulatory Integration }
$$

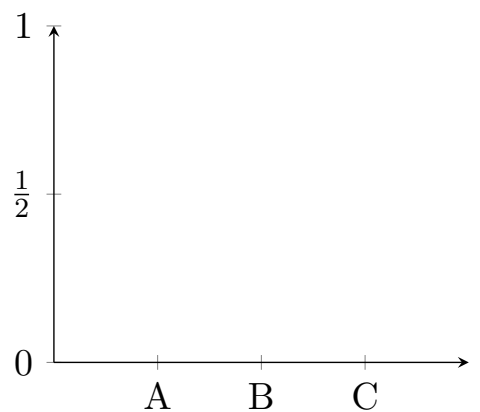

Panel B: Regulatory Integration Index at $\mathbf{t}=\mathbf{2}$

At $\mathrm{t}=2$, B implements the law. The bilateral link between A and B is activated. A (B) is integrated with one out of the two other countries. A(B)'s index value increases to 0.5 since one of its two possible links is activated.
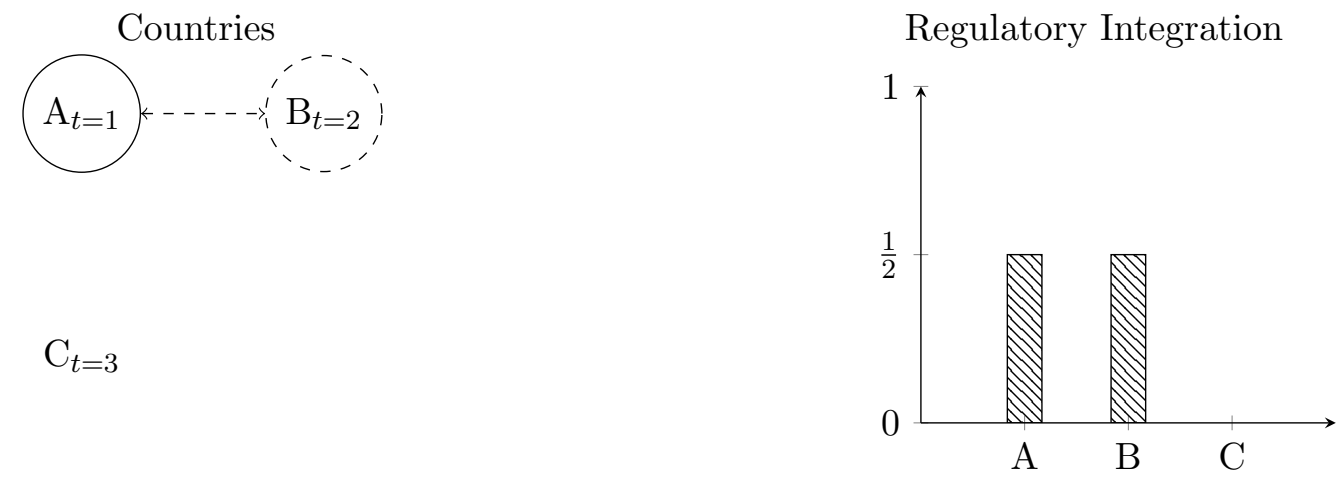

\section{Panel C: Regulatory Integration Index at $\mathrm{t}=\mathbf{3}$}

At $\mathrm{t}=3, \mathrm{C}$ implements the law. This activates the links between $\mathrm{A}(\mathrm{B})$ and $\mathrm{C}$. The index value increases from 0.5 to 1 for $\mathrm{A}$ and $\mathrm{B}$, since both countries are integrated with one additional country. The index value for $\mathrm{C}$ increases from 0 to 1 , since it is integrated with two additional countries.

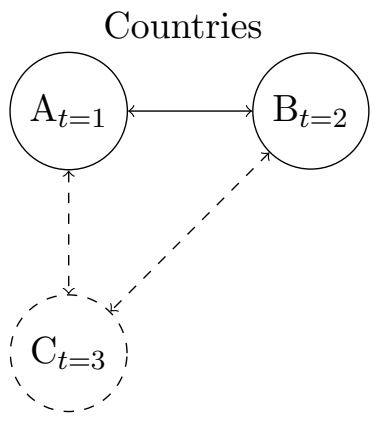

Regulatory Integration

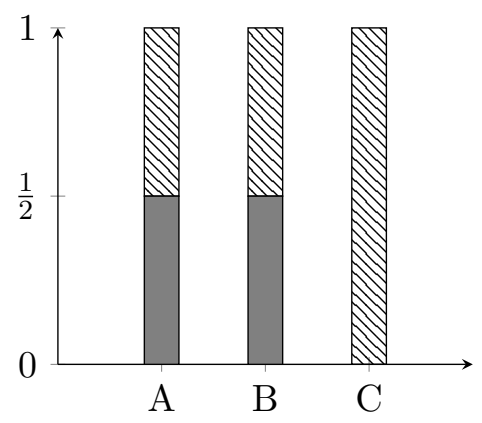




\section{Figure 2: Yearly Average of Regulatory Integration Index}

This figure presents the yearly average of the regulatory integration index, computed by equally weighting the yearly value of the index across the countries that are implementing the laws in the sample. See Figure 1 for an illustration of the index.

Panel A: Yearly Average of Regulatory Integration Index across Europe

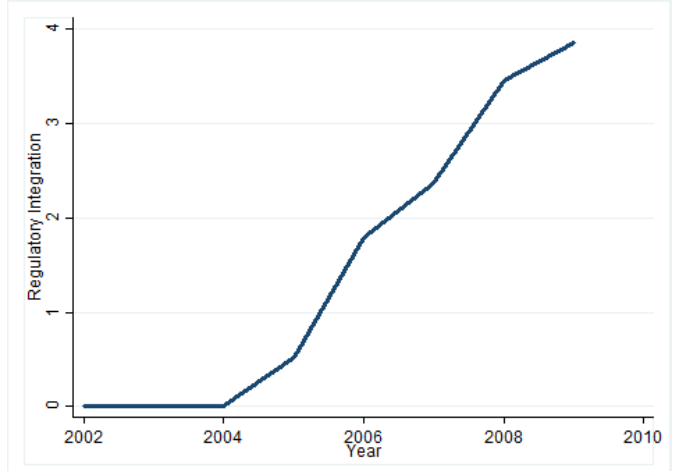

Panel B: Yearly Average of Regulatory Integration Index: Italy vs. Spain

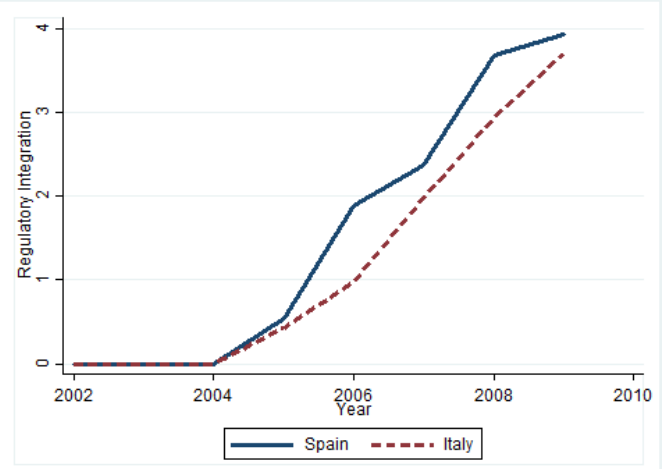




\section{Figure 3: First Refinement of Regulatory Integration Index}

This figure illustrates the regulatory integration takeout index - the first refinement of the baseline index (for detail see Subsection 3.4). I only keep that part of the index that comes from other countries' implementation and I discard the part of the index that is due to the country's own implementation. The refined index of a country is driven only by other countries' implementation timing, and not by the country's own implementation timing. This alleviates endogeneity concerns with respect to the implementation timing. Changes in the contemporaneous (preceding) time $\operatorname{period}(\mathrm{s})$ are represented with dashed (solid) circles, arrows or bars.

\section{Panel A: Regulatory Integration Takeout Index at $\mathbf{t}=\mathbf{1}$}

A implements the law at $t=1$. Its index value is 0 , because the other countries have not implemented the law yet.
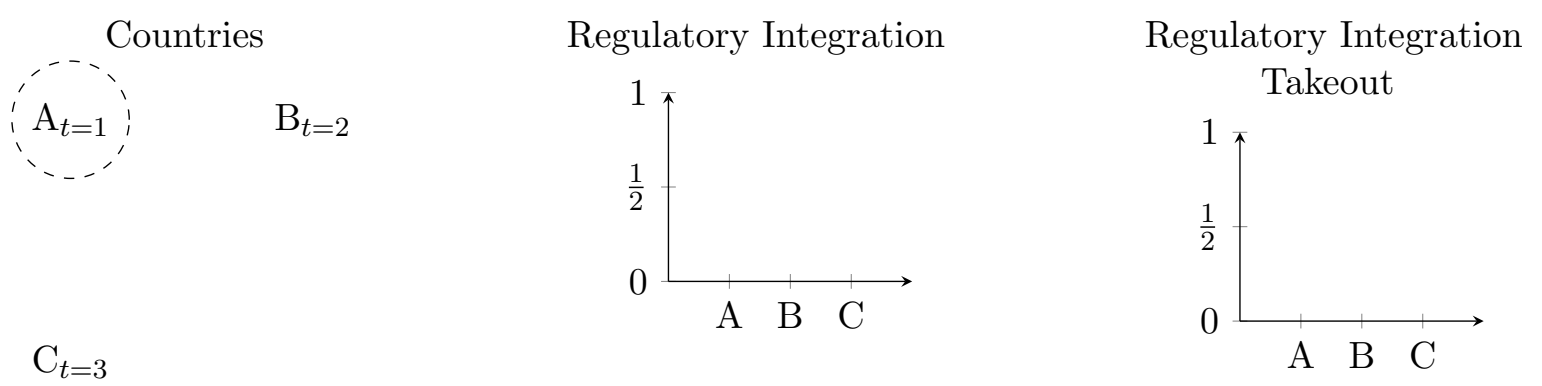

\section{Panel B: Regulatory Integration Takeout Index at $\mathbf{t}=\mathbf{2}$}

At $\mathrm{t}=2$, $\mathrm{B}$ implements the law. This activates the link between $\mathrm{A}$ and $\mathrm{B}$. For the refined index the index value of $A$, which implemented the law first, changes to 0.5 , while for $B$ the index value is 0 , because the fact that $\mathrm{B}$ is also integrated with $\mathrm{A}$ is discarded when computing B's index value.
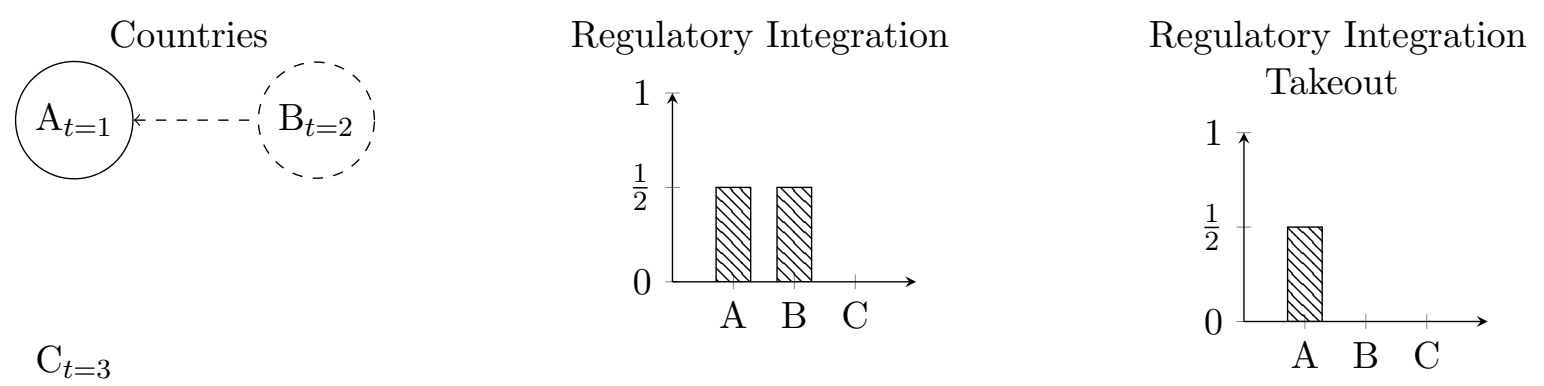

\section{Panel C: Regulatory Integration Takeout Index at $\mathbf{t}=\mathbf{3}$}

At $\mathrm{t}=3, \mathrm{C}$ implements the law. The implementation by $\mathrm{C}$ activates the links between $\mathrm{A}(\mathrm{B})$ and C. Only the effect of C's implementation on A and B is taken into account when computing the three countries' values for the refined index. In contrast, the effect that C's implementation has on its own index value is discarded. Since A and B are integrated with one more country, their index values increase by 0.5 each, to 1 for $\mathrm{A}$ and to 0.5 for $\mathrm{B}$. The index value for $\mathrm{C}$ remains 0 .
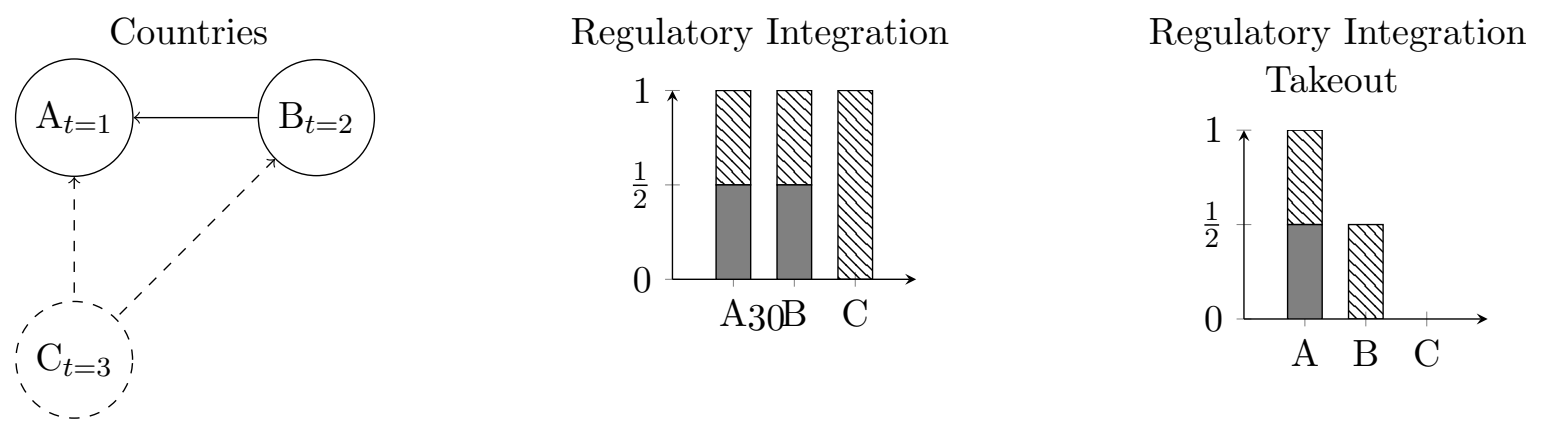


\section{Figure 4: Second Refinement of Regulatory Integration Index}

This figure illustrates the regulatory integration takeout big 4 index - the second refinement of the baseline index (for detail see Subsection 3.5). This refined index addresses the concern that countries time their implementation strategically with respect to other countries. I extend the example to four countries, with $\mathrm{A}$ and $\mathrm{C}$ being large countries. I drop $\mathrm{A}$ and $\mathrm{C}$ from the sample and only use them for the computation of the index. I also discard the effect of the country's own implementation on its index value. Changes in the contemporaneous (preceding) time period(s) are represented with dashed (solid) circles, arrows or bars.

Panel A: Regulatory Integration Takeout Big 4 Index at $\mathrm{t}=1$

At $\mathrm{t}=1$, A implements the law. Since A is a large country, it is excluded from the sample.

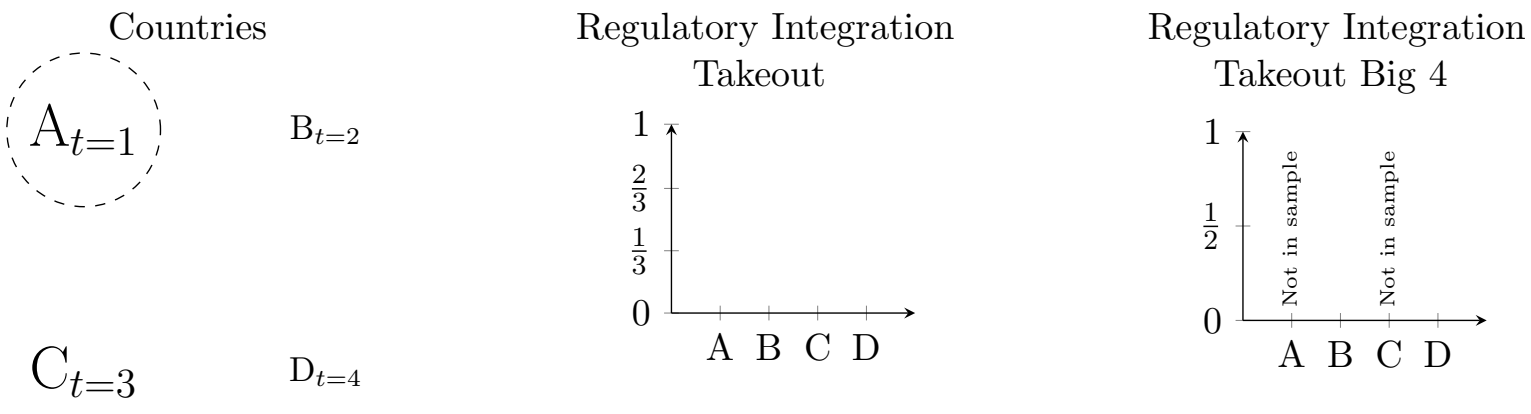

Panel B: Regulatory Integration Takeout Big 4 Index at $\mathrm{t}=\mathbf{2}$

At $\mathrm{t}=2, \mathrm{~B}$ implements the law. This activates the link between A and B. B's index value remains 0 , since I am discarding the effect of the country's own implementation on its index value.

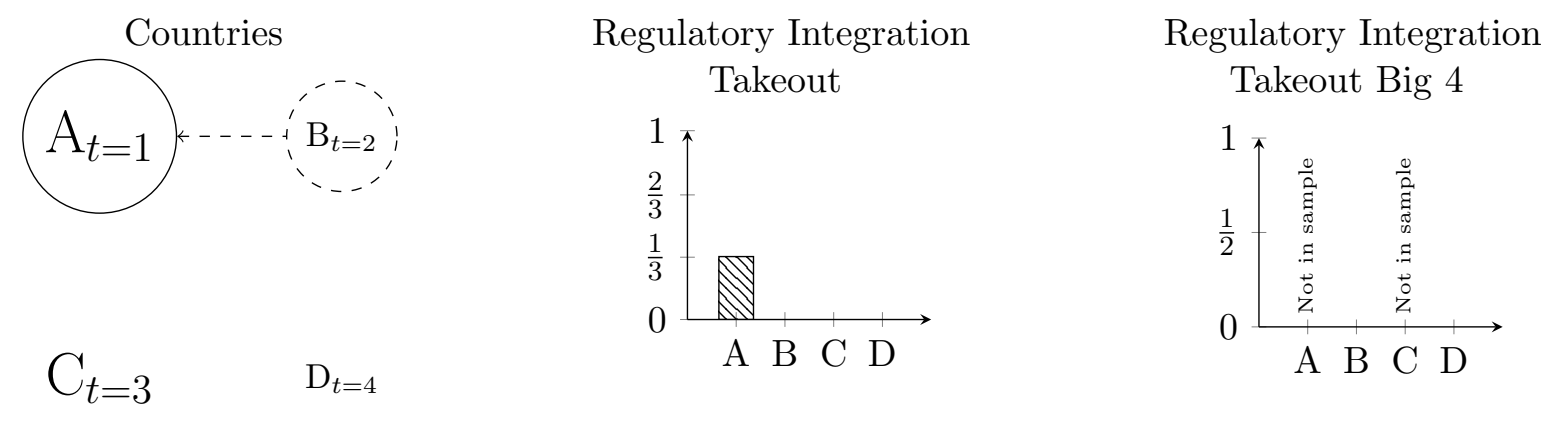

Panel C: Regulatory Integration Takeout Big 4 Index at $\mathrm{t}=\mathbf{3}$

At $\mathrm{t}=3$, C implements the law. This activates the links between A (B) and C. As only small countries remain in the sample, I discard the link between A and C. Since the link between the large country $\mathrm{C}$ and the small country $\mathrm{B}$ is activated by $\mathrm{C}$, the index value of $\mathrm{B}$ increases by 0.5 (one out of its two possible links with large countries has been activated). Since A and $\mathrm{C}$ are large countries, I do not compute their index values.
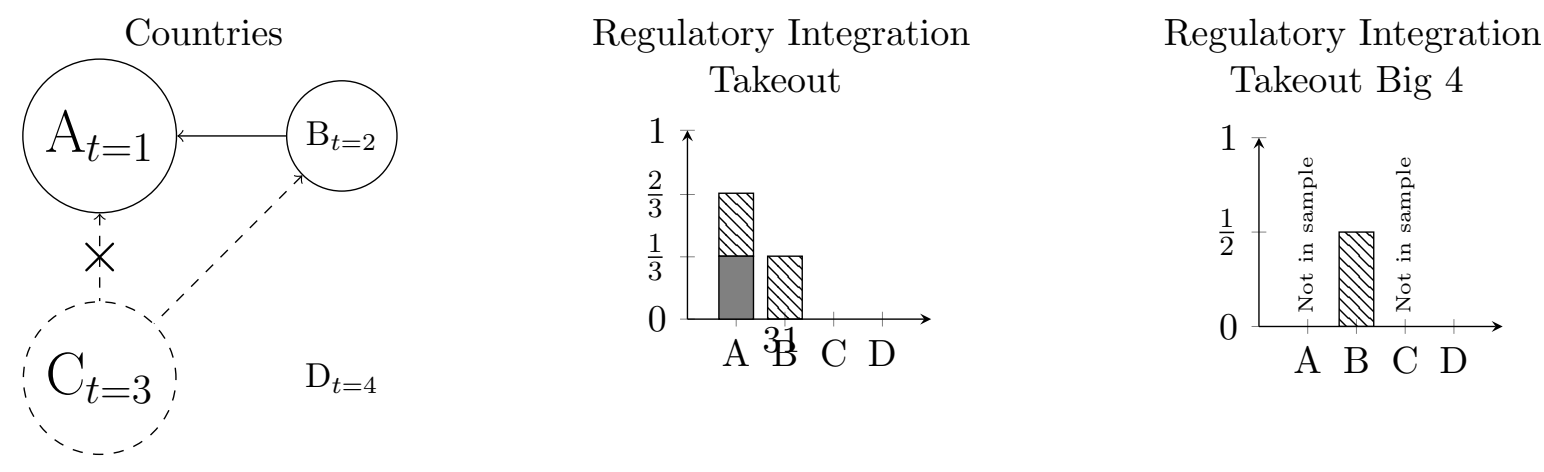


\section{Figure 4: Second Refinement of Regulatory Integration Index (Continued)}

\section{Panel D: Regulatory Integration Takeout Big 4 Index at $\mathrm{t}=4$}

At $\mathrm{t}=4$, D implements the law. This activates the links between A (B) [C] and D. Since I only consider links between large and small countries, the link between B and D is discarded. Since D activated its own links with the large countries A and C, I ignore these two links when computing D's refined index value. I do not compute this refined index for the large countries A and C. Therefore, the index values for the regulatory integration takeout big 4 index do not change at $\mathrm{t}=4$.

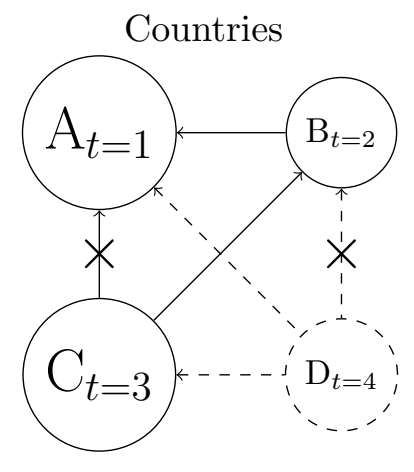

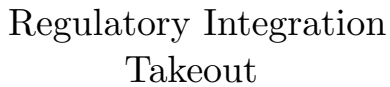

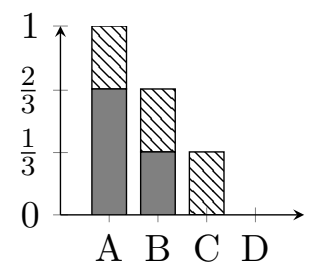

Regulatory Integration

Takeout Big 4

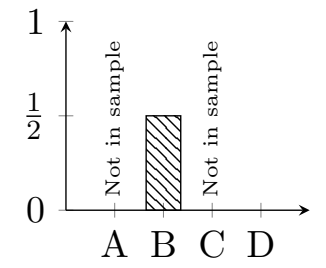

\section{Table 1: Countries in Sample}

This table presents the 21 European countries in the sample. Using a definition from the United Nations Statistics Division, I divide Europe into four regions. I classify European countries as large, if they are part of the Group of Seven (G7), which is an informal bloc of industrialized democracies.

\begin{tabular}{lcclcc}
\hline \hline Country & Region & Large Country & Country & Region & Large Country \\
\hline Austria & West & No & Luxembourg & West & No \\
Belgium & West & No & Netherlands & West & No \\
Czech Republic & East & No & Norway & North & No \\
Denmark & North & No & Poland & East & No \\
Finland & North & No & Portugal & South & No \\
France & West & Yes & Slovakia & East & No \\
Germany & West & Yes & Spain & South & No \\
Greece & South & No & Sweden & North & No \\
Hungary & East & No & Switzerland & West & No \\
Ireland & North & No & United Kingdom & North & Yes \\
Italy & South & Yes & & & \\
\hline \hline
\end{tabular}




\section{Table 2: Variable Definitions}

This table presents the variable definitions (for the indexes of regulatory integration see the corresponding figures). The source for accounting and share price data is Worldscope. All ratios are winsorized at the $1 \%$ level on both sides of the distribution.

\begin{tabular}{|c|c|}
\hline Variable & Definitions \\
\hline Net External Finance & Sum of net debt issues and net equity issues. \\
\hline Net Debt Issues & Total debt in t minus total debt in $\mathrm{t}-1$, divided by total assets in $\mathrm{t}-1$. \\
\hline Net Equity Issues & $\begin{array}{l}\text { Difference of net proceeds from sale/issue of common/preferred stock and } \\
\text { common/preferred stock redeemed, retired, converted (both year t), di- } \\
\text { vided by book value of total assets in t- } 1 \text {. }\end{array}$ \\
\hline Currency Regime & Coarse currency regime coding of Ilzetzki, Reinhart, and Rogoff (2011). \\
\hline EU Accession & Dummy that turns 1, when a country joins the EU. \\
\hline Real GDP Growth & $\begin{array}{l}\text { Annual year-on-year percentage change in constant price GDP (World } \\
\text { Economic Outlook database (International Monetary Fund }(2015) \text { )). }\end{array}$ \\
\hline Inflation & $\begin{array}{l}\text { Annual year-on-year percentage change of consumer prices (World Eco- } \\
\text { nomic Outlook database (International Monetary Fund }(2015)) \text { ). }\end{array}$ \\
\hline Tobin's Q & Total assets minus book equity plus stock market value, over total assets. \\
\hline Book Equity & $\begin{array}{l}\text { Total assets minus total liabilities minus preferred stock plus deferred } \\
\text { income taxes and investment tax credit. }\end{array}$ \\
\hline EBITDA/AT & EBITDA over total assets. \\
\hline Market Lev. & Total debt over total debt minus book equity plus stock market value. \\
\hline Collateral/AT & Net property, plant and equipment plus inventories over total assets. \\
\hline Cash/AT & Cash over total assets. \\
\hline Sales Gr. & Annual growth rate in net sales. \\
\hline $\ln (\mathrm{USD} \mathrm{MCAP})$ & Logarithm of the stock market capitalization in constant 2014 USD. \\
\hline
\end{tabular}

Table 3: Summary Statistics

This table presents the summary statistics. The sample contains publicly traded companies from 21 countries (Table 1). Variable definitions are in Table 2. The sample ranges from 1990 to 2009. Financials and utilities are excluded from the sample. Unless stated otherwise, the independent variables are lagged one year compared to the dependent variable in a regression specification.

\begin{tabular}{lccclccc}
\hline \hline Variable & Mean & St. Dev. & $\mathrm{N}$ & Variable & Mean & St. Dev. & $\mathrm{N}$ \\
\hline Net External Finance & 4.97 & 17.97 & 50,774 & EBITDA/AT & 11.30 & 10.93 & 50,774 \\
Regulatory Integration & 0.44 & 0.98 & 50,774 & Market Lev. & 19.14 & 17.01 & 50,774 \\
Currency Regime & 2.03 & 1.05 & 50,774 & Collateral/AT & 45.61 & 25.59 & 50,774 \\
EU Accession & 0.08 & 0.28 & 50,774 & Cash/AT & 11.92 & 13.71 & 50,774 \\
Real GDP Growth & 2.03 & 2.22 & 50,774 & Sales Gr. & 17.61 & 55.71 & 50,774 \\
Inflation & 2.32 & 1.61 & 50,774 & $\ln$ (USD MCAP) & 19.32 & 1.70 & 50,774 \\
Tobin's Q & 1.51 & 0.97 & 50,774 & & & & \\
\hline \hline
\end{tabular}


Table 4: Main Result - The Impact of Regulatory Integration on External Financing

This table documents the effect of regulatory integration of international capital markets on external financing. The dependent variable is net external finance. The regulatory integration index is explained in Figure 1. For the other variables see Table 2. (Lag.) Real GDP growth and (lag.) inflation are contemporaneous (from the prior year). All other explanatory variables are lagged one year. Firm FE refers to firm fixed effects. Year FE refers to year fixed effects. Year $\times$ Ind. $(x$ Region) FE refers to fixed effects for the interaction of years, 3-digit SIC code industries(, and the 4 European regions (see Table 1)). Standard errors are clustered at the country level. P-values are reported in parentheses. ${ }^{* * *},{ }^{* *}$ and $*$ denote significance at the $1 \%, 5 \%$ and $10 \%$ levels.

\begin{tabular}{|c|c|c|c|c|c|}
\hline & \multicolumn{5}{|c|}{ Net External Finance } \\
\hline & $(1)$ & $(2)$ & $(3)$ & $(4)$ & $(5)$ \\
\hline \multirow[t]{2}{*}{ Regulatory Integration } & $1.30^{* * *}$ & $1.43^{* * *}$ & $1.06^{* * *}$ & $0.83^{* * *}$ & $1.14^{* * *}$ \\
\hline & $(0.00)$ & $(0.00)$ & $(0.00)$ & $(0.00)$ & $(0.00)$ \\
\hline \multirow[t]{2}{*}{ Currency Regime } & & -0.20 & -0.14 & -0.22 & -0.17 \\
\hline & & $(0.18)$ & $(0.37)$ & $(0.11)$ & $(0.53)$ \\
\hline \multirow[t]{2}{*}{ EU Accession } & & -0.42 & $-3.81^{* * *}$ & $-3.67^{* * *}$ & $-3.26^{*}$ \\
\hline & & $(0.46)$ & $(0.01)$ & $(0.00)$ & $(0.05)$ \\
\hline \multirow[t]{2}{*}{ Real GDP Growth } & & 0.13 & -0.17 & -0.14 & -0.06 \\
\hline & & $(0.14)$ & $(0.18)$ & $(0.25)$ & $(0.66)$ \\
\hline \multirow[t]{2}{*}{ Inflation } & & -0.02 & $-0.35^{* *}$ & $-0.34^{* * *}$ & $-0.29^{* *}$ \\
\hline & & $(0.83)$ & $(0.02)$ & $(0.01)$ & $(0.04)$ \\
\hline \multirow[t]{2}{*}{ lag. Real GDP Growth } & & $0.41^{* * *}$ & $0.18^{* *}$ & 0.12 & 0.12 \\
\hline & & $(0.00)$ & $(0.04)$ & $(0.18)$ & $(0.26)$ \\
\hline \multirow[t]{2}{*}{ lag. Inflation } & & 0.20 & 0.02 & 0.07 & $0.30^{*}$ \\
\hline & & $(0.12)$ & $(0.89)$ & $(0.58)$ & $(0.07)$ \\
\hline \multirow[t]{2}{*}{ Tobin's Q } & & $3.58^{* * *}$ & $4.93^{* * *}$ & $4.95^{* * *}$ & $5.13^{* * *}$ \\
\hline & & $(0.00)$ & $(0.00)$ & $(0.00)$ & $(0.00)$ \\
\hline \multirow[t]{2}{*}{ EBITDA/AT } & & $-14.96^{* * *}$ & $3.14^{* *}$ & $3.19^{* *}$ & $2.76^{*}$ \\
\hline & & $(0.00)$ & $(0.04)$ & $(0.03)$ & $(0.06)$ \\
\hline \multirow[t]{2}{*}{ Market Lev. } & & $-6.94^{* * *}$ & $-50.38^{* * *}$ & $-52.89^{* * *}$ & $-56.15^{* * *}$ \\
\hline & & $(0.00)$ & $(0.00)$ & $(0.00)$ & $(0.00)$ \\
\hline \multirow[t]{2}{*}{ Collateral/AT } & & $3.24^{* * *}$ & 1.86 & 1.94 & 1.66 \\
\hline & & $(0.00)$ & $(0.45)$ & $(0.45)$ & $(0.52)$ \\
\hline \multirow[t]{2}{*}{ Cash/AT } & & $-3.97^{* * *}$ & $-11.80^{* * *}$ & $-12.04^{* * *}$ & $-12.80^{* * *}$ \\
\hline & & $(0.00)$ & $(0.00)$ & $(0.00)$ & $(0.00)$ \\
\hline \multirow[t]{2}{*}{ Sales Gr. } & & $3.43^{* * *}$ & $0.60^{*}$ & $0.53^{*}$ & $0.58^{*}$ \\
\hline & & $(0.00)$ & $(0.05)$ & $(0.10)$ & $(0.08)$ \\
\hline \multirow[t]{2}{*}{$\ln (\mathrm{USD} \mathrm{MCAP})$} & & $-0.45^{* *}$ & $-4.01^{* * *}$ & $-4.46^{* * *}$ & $-4.85^{* * *}$ \\
\hline & & $(0.02)$ & $(0.00)$ & $(0.00)$ & $(0.00)$ \\
\hline Adj. $R^{2}$ & 0.02 & 0.07 & 0.22 & 0.22 & 0.22 \\
\hline $\mathrm{N}$ & 50,774 & 50,774 & 50,774 & 50,774 & 50,774 \\
\hline Firm FE & No & No & Yes & Yes & Yes \\
\hline Year FE & Yes & Yes & Yes & Absorbed & Absorbed \\
\hline Year $\times$ Ind & No & No & No & Yes & Absorbed \\
\hline Year $\times$ Ind.$\times$ Region FE & No & No & No & No & Yes \\
\hline Cluster & Country & Country & Country & Country & Country \\
\hline
\end{tabular}




\section{Table 5: Real Effects - The Use of the Additional Financing}

This table documents the relationship between regulatory integration of international capital markets and real outcomes. The dependent variable in column 1 is the investment rate, which is contemporaneous capital expenditures over total assets in the prior year. The dependent variable in column 2 is the logarithm of the number of employees of a company, winsorized at the $5 \%$ level. The regulatory integration index is illustrated in Figure 1. All control variables from Table 4 are included but not displayed. Firm FE refers to firm fixed effects. Year $\times$ Ind. $\times$ Region FE refers to fixed effects for the interaction of years, 3-digit SIC code industries, and the 4 European regions (see Table 1). Standard errors are clustered at the country level. P-values are reported in parentheses. $* * *, * *$ and $*$ denote significance at the $1 \%, 5 \%$ and $10 \%$ levels.

\begin{tabular}{lcc}
\hline \hline & $(1)$ & $(2)$ \\
& Investment Rate & $\log ($ Employees $)$ \\
\hline Regulatory Integration & $0.43^{* * *}$ & $2.65^{*}$ \\
& $(0.00)$ & $(0.05)$ \\
\hline Adj. $R^{2}$ & 0.48 & 0.94 \\
$\mathrm{~N}$ & 50,774 & 47,414 \\
Firm FE & Yes & Yes \\
Year $\times$ Ind. $\times$ Region FE & Yes & Yes \\
Cluster & Country & Country \\
Controls & Yes & Yes \\
\hline \hline
\end{tabular}




\section{Table 6: Identification - Endogeneity in Timing of Implementation of Laws}

This table documents the relationship between regulatory integration of international capital markets and net external finance, using different indexes of regulatory integration. The dependent variable is net external finance. The index of regulatory integration in columns 1 and 3 is the regulatory integration takeout index, which is illustrated in Figure 3. The index of regulatory integration in column 2 is the regulatory integration index, which is illustrated in Figure 1. The index of regulatory integration in column 4 is the regulatory integration takeout big 4 index, which is illustrated in Figure 4. In columns 2 to 4, firms from the four large countries France, Germany, Italy and the United Kingdom are excluded from the sample (see Table 1). All control variables from Table 4 are included but not displayed. Firm FE refers to firm fixed effects. Year $\times$ Ind. $\times$ Region FE refers to fixed effects for the interaction of years, 3-digit SIC code industries, and the 4 European regions (see Table 1). Standard errors are clustered at the country level. P-values are reported in parentheses. $* * *, * *$ and $*$ denote significance at the $1 \%, 5 \%$ and $10 \%$ levels.

\begin{tabular}{lcccc}
\hline \hline & \multicolumn{3}{c}{ Net External Finance } \\
& $(1)$ & $(2)$ & $(3)$ & $(4)$ \\
\hline Regulatory Integration & \multicolumn{4}{c}{$1.59^{* *}$} \\
& $(0.02)$ & \\
Regulatory Integration Takeout & $1.41^{* * *}$ & & $2.96^{* * *}$ & \\
& $(0.00)$ & & $(0.00)$ & \\
Regulatory Integration Takeout Big 4 & & & $2.93^{* * *}$ \\
& & & & $(0.00)$ \\
\hline Adj. $R^{2}$ & 0.22 & 0.16 & 0.16 & 0.16 \\
$\mathrm{~N}$ & 50,774 & 16,937 & 16,937 & 16,937 \\
Firm FE & Yes & Yes & Yes & Yes \\
Year $\times$ Ind. $\times$ Region FE & Yes & Yes & Yes & Yes \\
Cluster & Country & Country & Country & Country \\
Controls & Yes & Yes & Yes & Yes \\
Sample & All & No Big 4 & No Big 4 & No Big 4 \\
\hline \hline
\end{tabular}




\section{Table 7: Identification - Macro Shocks and Trends - External Finance Dependence}

This table documents the relationship between regulatory integration of international capital markets and net external finance, while accounting for differences in external finance dependence across industries. The dependent variable is net external finance. A proxy for external finance dependence following Rajan and Zingales (1998) is constructed. This proxy is standardized so that it ranges from 0 to 1 . This proxy of external finance dependence is interacted with the regulatory integration index (see Figure 1). All control variables from Table 4 are included but not displayed. Firm FE refers to firm fixed effects. Year $\times$ Ind. $(\times$ Region $)$ FE refers to fixed effects for the interaction of years, 3-digit SIC code industries(, and the 4 European regions (see Table 1)). Year $\times$ Country FE refers to fixed effects for the interaction of years and countries. Standard errors are clustered at the country level. P-values are reported in parentheses. ***, ** and ${ }^{*}$ denote significance at the $1 \%$, $5 \%$ and $10 \%$ levels.

\begin{tabular}{lcc}
\hline \hline & \multicolumn{2}{c}{ Net External Finance } \\
& $(1)$ & $(2)$ \\
\hline Regulatory Integration $\times$ External Finance Dependence & $4.80^{*}$ & $6.78^{* *}$ \\
& $(0.08)$ & $(0.02)$ \\
\hline Adj. $R^{2}$ & 0.23 & 0.22 \\
$\mathrm{~N}$ & 49,285 & 49,285 \\
Firm FE & Yes & Yes \\
Year $\times$ Ind. & Yes & Absorbed \\
Year $\times$ Ind. $\times$ Region FE & No & Yes \\
Year $\times$ Country FE & Yes & Yes \\
Cluster & Country & Country \\
Firm Controls & Yes & Yes \\
Macro Controls & Absorbed & Absorbed \\
\hline \hline
\end{tabular}




\section{Table 8: Channel - Net Debt Issues and Net Equity Issues}

This table documents the relationship between regulatory integration of international capital markets, and net debt issues and net equity issues. The dependent variables are net debt issues and net equity issues, which are defined in Table 2. The regulatory integration index is illustrated in Figure 1. All control variables from Table 4 are included but not displayed. Firm FE refers to firm fixed effects. Year $\times$ Ind. $\times$ Region FE refers to fixed effects for the interaction of years, 3-digit SIC code industries, and the 4 European regions (see Table 1). Standard errors are clustered at the country level. P-values are reported in parentheses. ${ }^{* * *},{ }^{* *}$ and ${ }^{*}$ denote significance at the $1 \%$, $5 \%$ and $10 \%$ levels.

\begin{tabular}{lcc}
\hline \hline & $(1)$ & $(2)$ \\
& Net Debt Issues & Net Equity Issues \\
\hline Regulatory Integration & $1.03^{* * *}$ & 0.07 \\
& $(0.00)$ & $(0.60)$ \\
\hline Adj. $R^{2}$ & 0.17 & 0.23 \\
$\mathrm{~N}$ & 50,774 & 50,774 \\
Firm FE & Yes & Yes \\
Year $\times$ Ind. $\times$ Region FE & Yes & Yes \\
Cluster & Country & Country \\
Controls & Yes & Yes \\
\hline \hline
\end{tabular}




\section{Table 9: Channel - Change in Sample Composition through Entry or Exit}

This table documents the analysis of potential changes in the sample composition of publicly listed companies through entry or exit. The dependent variable in columns 1 and 2 is the entry rate, defined as the number of initial public offerings (IPOs) in a country in a given year, divided by the number of publicly listed companies in the same country in the prior year. The dependent variable in columns 3 and 4 is the exit rate, defined as the number of delistings in a country in a given year, divided by the number of publicly listed companies in the same country in the prior year. The dependent variable in columns 5 and 6 is the net entry rate, which is the difference between the entry rate and the exit rate in a country in a given year. The regulatory integration index is illustrated in Figure 1. All macroeconomic control variables from Table 4 are included but not displayed. In columns 2, 4 and 6, I additionally control for determinants of IPO activity identified by the IPO literature: The stock market return in a country, the stock price volatility in a country, and the Tobin's Q of the stocks in a country. Country FE refers to country fixed effects. Year $\times$ Region FE refers to fixed effects for the interaction of years and 4 European regions (see Table 1). Standard errors are clustered at the country level. P-values are reported in parentheses. ***, ** and ${ }^{*}$ denote significance at the $1 \%, 5 \%$ and $10 \%$ levels.

\begin{tabular}{lcccccc}
\hline \hline & \multicolumn{2}{c}{ Entry Rate } & \multicolumn{2}{c}{ Exit Rate } & \multicolumn{2}{c}{ Net Entry Rate } \\
& $(1)$ & $(2)$ & $(3)$ & $(4)$ & $(5)$ & $(6)$ \\
\hline Regulatory Integration & 0.20 & -0.03 & -0.13 & -0.12 & 0.33 & 0.09 \\
& $(0.44)$ & $(0.88)$ & $(0.56)$ & $(0.66)$ & $(0.37)$ & $(0.81)$ \\
\hline Adj. $R^{2}$ & 0.23 & 0.47 & 0.34 & 0.33 & 0.35 & 0.46 \\
$\mathrm{~N}$ & 292 & 292 & 292 & 292 & 292 & 292 \\
Country FE & Yes & Yes & Yes & Yes & Yes & Yes \\
Year $\times$ Region FE & Yes & Yes & Yes & Yes & Yes & Yes \\
Cluster & Country & Country & Country & Country & Country & Country \\
Macro controls & Yes & Yes & Yes & Yes & Yes & Yes \\
Stock Market Controls & No & Yes & No & Yes & No & Yes \\
\hline \hline
\end{tabular}




\section{Table 10: Channel - Euro Currency Union and European Regions}

This table documents cross-sectional differences in the effect of regulatory integration of international capital markets on external financing across different countries and European regions. The dependent variable is net external finance. The regulatory integration index is illustrated in Figure 1. The regulatory integration index is interacted with geographic variables. Euro denotes the euro currency countries. South indicates the four Southern European countries in the sample: Portugal, Italy, Greece and Spain. Euro Not South stands for the euro currency countries, with the exception of the four Southern European countries. North, West and East are the three other European regions, which are defined in Table 1 . All control variables from Table 4 are included but not displayed. Firm FE refers to firm fixed effects. Year FE refers to year fixed effects. Standard errors are clustered at the country level. P-values are reported in parentheses. ${ }^{* * *},{ }^{* *}$ and ${ }^{*}$ denote significance at the $1 \%, 5 \%$ and $10 \%$ levels.

\begin{tabular}{|c|c|c|c|c|c|}
\hline & \multicolumn{5}{|c|}{ Net External Finance } \\
\hline & $(1)$ & $(2)$ & $(3)$ & $(4)$ & $(5)$ \\
\hline Regulatory Integration & $\begin{array}{l}0.47^{* *} \\
(0.03)\end{array}$ & $\begin{array}{c}0.79^{* * *} \\
(0.00)\end{array}$ & $\begin{array}{c}0.77^{* * *} \\
(0.00)\end{array}$ & $\begin{array}{c}0.56^{* * *} \\
(0.00)\end{array}$ & \\
\hline Regulatory Integration $\times$ Euro & $\begin{array}{c}0.63^{* * *} \\
(0.00)\end{array}$ & & & & \\
\hline Regulatory Integration $\times$ South & & $\begin{array}{c}1.13^{* * *} \\
(0.00)\end{array}$ & & $\begin{array}{c}1.37^{* * *} \\
(0.00)\end{array}$ & $\begin{array}{c}1.98^{* * *} \\
(0.00)\end{array}$ \\
\hline Regulatory Integration $\times$ Euro Not South & & & & $\begin{array}{l}0.42^{* *} \\
(0.01)\end{array}$ & \\
\hline Regulatory Integration $\times$ Portugal & & & $\begin{array}{c}0.07 \\
(0.79)\end{array}$ & & \\
\hline Regulatory Integration $\times$ Italy & & & $\begin{array}{c}0.86^{* * *} \\
(0.00)\end{array}$ & & \\
\hline Regulatory Integration $\times$ Greece & & & $\begin{array}{c}1.63^{* * *} \\
(0.00)\end{array}$ & & \\
\hline Regulatory Integration $\times$ Spain & & & $\begin{array}{c}0.95^{* * *} \\
(0.01)\end{array}$ & & \\
\hline Regulatory Integration $\times$ North & & & & & $\begin{array}{c}0.70^{* * * *} \\
(0.01)\end{array}$ \\
\hline Regulatory Integration $\times$ West & & & & & $\begin{array}{c}0.94^{* * *} \\
(0.00)\end{array}$ \\
\hline Regulatory Integration $\times$ East & & & & & $\begin{array}{c}2.28^{* * * *} \\
(0.01)\end{array}$ \\
\hline Adj. $R^{2}$ & 0.22 & 0.22 & 0.22 & 0.22 & 0.22 \\
\hline $\mathrm{N}$ & 50,774 & 50,774 & 50,774 & 50,774 & 50,774 \\
\hline Firm FE & Yes & Yes & Yes & Yes & Yes \\
\hline Year $\times$ Ind & Yes & Yes & Yes & Yes & Yes \\
\hline Cluster & Country & Country & Country & Country & Country \\
\hline Controls & Yes & Yes & Yes & Yes & Yes \\
\hline
\end{tabular}




\section{Index of Working Papers:}

\begin{tabular}{|c|c|c|c|}
\hline $\begin{array}{l}\text { March 5, } \\
2015\end{array}$ & $\begin{array}{l}\text { Jonas Dovern, } \\
\text { Martin Feldkircher, } \\
\text { Florian Huber }\end{array}$ & 200 & $\begin{array}{l}\text { Does Joint Modelling of the World Economy } \\
\text { Pay Off? Evaluating Global Forecasts from a } \\
\text { Bayesian GVAR }\end{array}$ \\
\hline $\begin{array}{l}\text { May 19, } \\
2015\end{array}$ & Markus Knell & 201 & $\begin{array}{l}\text { The Return on Social Security with } \\
\text { Increasing Longevity }\end{array}$ \\
\hline $\begin{array}{l}\text { June 15, } \\
2015\end{array}$ & Anil Ari & 202 & Sovereign Risk and Bank Risk-Taking \\
\hline $\begin{array}{l}\text { June 15, } \\
2015\end{array}$ & Matteo Crosignani & 203 & $\begin{array}{l}\text { Why Are Banks Not Recapitalized During } \\
\text { Crises? }\end{array}$ \\
\hline $\begin{array}{l}\text { February 19, } \\
2016\end{array}$ & Burkhard Raunig & 204 & Background Indicators \\
\hline $\begin{array}{l}\text { February 22, } \\
2016\end{array}$ & $\begin{array}{l}\text { Jesús Crespo } \\
\text { Cuaresma, } \\
\text { Gernot Doppelhofer, } \\
\text { Martin Feldkircher, } \\
\text { Florian Huber }\end{array}$ & 205 & US Monetary Policy in a Globalized World \\
\hline $\begin{array}{l}\text { March 4, } \\
2016\end{array}$ & $\begin{array}{l}\text { Helmut Elsinger, } \\
\text { Philipp Schmidt- } \\
\text { Dengler, } \\
\text { Christine Zulehner }\end{array}$ & 206 & Competition in Treasury Auctions \\
\hline $\begin{array}{l}\text { May 14, } \\
2016\end{array}$ & $\begin{array}{l}\text { Apostolos } \\
\text { Thomadakis }\end{array}$ & 207 & $\begin{array}{l}\text { Determinants of Credit Constrained Firms: } \\
\text { Evidence from Central and Eastern Europe } \\
\text { Region }\end{array}$ \\
\hline $\begin{array}{l}\text { July 1, } \\
2016\end{array}$ & $\begin{array}{l}\text { Martin Feldkircher, } \\
\text { Florian Huber }\end{array}$ & 208 & $\begin{array}{l}\text { Unconventional US Monetary Policy: New } \\
\text { Tools Same Channels? }\end{array}$ \\
\hline $\begin{array}{l}\text { November 24, } \\
2016\end{array}$ & François de Soyres & 209 & $\begin{array}{l}\text { Value Added and Productivity Linkages } \\
\text { Across Countries }\end{array}$ \\
\hline $\begin{array}{l}\text { November 25, } \\
2016\end{array}$ & Maria Coelho & 210 & $\begin{array}{l}\text { Fiscal Stimulus in a Monetary Union: } \\
\text { Evidence from Eurozone Regions }\end{array}$ \\
\hline $\begin{array}{l}\text { January 9, } \\
2017\end{array}$ & $\begin{array}{l}\text { Markus Knell, } \\
\text { Helmut Stix }\end{array}$ & 211 & Inequality, Perception Biases and Trust \\
\hline
\end{tabular}




\begin{tabular}{llrl}
\hline $\begin{array}{l}\text { January 31, } \\
2017\end{array}$ & $\begin{array}{l}\text { Steve Ambler, } \\
\text { Fabio Rumler }\end{array}$ & $212 \begin{array}{l}\text { The Effectiveness of Unconventional } \\
\text { Monetary Policy Announcements in the Euro } \\
\text { Area: An Event and Econometric Study }\end{array}$ \\
\hline $\begin{array}{l}\text { May 29, } \\
2017\end{array}$ & Filippo De Marco & 213 & $\begin{array}{l}\text { Bank Lending and the European Sovereign } \\
\text { Debt Crisis }\end{array}$ \\
$\begin{array}{l}\text { June 1, } \\
2017\end{array}$ & Jean-Marie Meier & $214 \begin{array}{l}\text { Regulatory Integration of International } \\
\text { Capital Markets }\end{array}$ \\
\hline
\end{tabular}

